\title{
POLITYKA ZACHODNIA CESARZA MARCJANA (450-457) Problem huński i jego wpływ na relacje między Cesarstwem Wschodnim a Zachodnim
}

Rządy cesarza Marcjana (450-457) są w historii późnego antyku okresem obfitującym w wydarzenia przełomowe dla epoki. W latach 450-453 doszło do starcia Hunów z Cesarstwem Zachodniorzymskim oraz do śmierci Attyli i upadku jego imperium. Aecjusz, zwany ostatnim Rzymianinem, zginął z ręki młodego cesarza Walentyniana w 454 r., zaś Rzym został zdobyty i splądrowany przez Wandalów Gejzeryka w rok później. W 456 r. do wysokich stanowisk dochodzi Rycymer, uważany za jednego z grabarzy cesarstwa na Zachodzie. Wymienione wydarzenia doczekały się oczywiście gruntownych analiz, jednak stosunkowo na uboczu pozostawiono kwestię, jak cesarz Marcjan, władca Bizancjum, pierwszoplanowego aktora politycznego na obszarze Mediterraneum, reagował na problemy Zachodu. Bardzo krytyczną analizę „dorobku” cesarza zaproponował Edward A. Thompson, zestawiając politykę Marcjana i Teodozjusza II $^{1}$, jednak jego twierdzenia spotkały się z polemiką ze strony Roberta L. Hohlfeldera, który docenił pragmatyczne i przemyślane działania tego władcy wobec Hunów ${ }^{2}$. Mimo to żadna z podanych prac w/w autorów nie wyczerpuje problemu, dlatego warto przeprowadzić dokładniejszą analizę tego tematu. Reinterpretacja polityki zachodniej Marcjana może przyczynić się do bliższego zrozumienia zawiłych mechanizmów kierujących polityką zewnętrzną Bizancjum.

1. Bilans polityki zachodniej Teodozjusza II. Przedstawienie polityki zachodniej cesarza Marcjana wymaga prześledzenia sytuacji geopolitycznej, w jakiej znajdowało się Cesarstwo tuż przed objęciem przez niego tronu. Poprzednik Marcjana, Teodozjusz II, był jednym z najdłużej panujących władców Imperium. Ze względu na to, że objął tron będąc nieletnim, w jego otoczeniu

\footnotetext{
* Mgr Łukasz Pigoński - doktorant w Katedrze Historii Bizancjum w Instytucie Historii na Wydziale Filozoficzno-Historycznym Uniwersytetu Lódzkiego; e-mail: pigonski@zoho.com.

${ }^{1}$ Por. E.A. Thompson, The Foreign Policies of Theodosius II and Marcian, „Hermathena” 76 (1950) 58-75.

${ }^{2}$ Por. R.L. Hohlfelder, Marcian's Gamble. A Reassessment of Eastern Imperial Policy toward Attila AD 450-453, „Americal Journal of Ancient History” 9 (1984) 54-69.
} 
znalazło się wiele wpływowych, choć niekoniecznie świetlanych postaci, które pozostając w cieniu jego tronu de facto kierowały sprawami państwa ${ }^{3}$. Źródła z tego okresu właśnie złym doradcom przypisują odpowiedzialność za wszelkie nieszczęścia, jakie spadły na Bizancjum, zaś władcę określają jako obdarzonego słabą wolą i niezdolnego do forsowania własnej polityki. Taką ostrą ocenę znajdujemy przede wszystkim u Pryskosa ${ }^{4}$. Nie sposób jednak oprzeć się wrażeniu, że to właśnie porażki w polityce zagranicznej, jakie ponosiło Bizancjum za panowania Teodozjusza II, wpłynęły na negatywne nastawienie historyka, który będąc dyplomatą, był szczególnie zainteresowany właśnie tymi sprawami. Nie można zapominać o osiagnięciach władcy w polityce wewnętrznej5, jednak większość jego przedsięwzięć dyplomatycznych, zwłaszcza w relacjach z ludami ościennymi, zakończyła się fiaskiem. Mimo to wydaje się, że niesprawiedliwe byłoby przypisywanie ich wyłącznie nieudolności władcy.

Teodozjusz II wyraźnie uznawał interes dynastii teodozjańskiej i dobro całości Imperium za nadrzędne elementy w swej polityce. Mimo formujących się różnic pomiędzy obiema częściami państwa, władca starał się utrzymywać relatywną jedność. Widoczne jest to m.in. w przypadku konfliktu z uzurpatorem Janem $^{6}$, który choć cieszył się poparciem w Italii, nie został uznany przez Teodozjusza II, stojącego na stanowisku, że tylko osoba z domu teodozjańskiego

${ }^{3}$ Przede wszystkim siostra Pulcheria oraz od 421 r. żona Atenais Eudocja. Por. K.G. Holum, Theodosian Empresses: Women and Imperial Dominion in Late Antiquity, The Transformation of the Clasical Heritage 3, Berkeley 1982, 79-145.

${ }^{4}$ Por. Priscus, Fragmenta 3, ed. R.C. Blockley, w: The Fragmentary Classicising Historians of the Later Roman Empire. Eunapius, Olympiodorus, Priscus and Malchus, vol. 2: Text, Translation and Historiographical Notes, Liverpool 1983, 226-229. Twórczość tego historyka jest absolutnie nieodzowna w badaniach nad polityką zewnętrzną Marcjana. Pryskos był urzędnikiem cesarskim i dyplomatą, zatem znał opisywaną problematykę z pierwszej ręki. Choć jego dzieło historyczne zachowało się wyłącznie fragmentarycznie, wielu późniejszych historyków bizantyńskich korzystało z niego opisując wydarzenia z V w. Więcej na temat Pryskosa: R.C. Blockley, The Fragmentary Classicising Historians of the Later Roman Empire, vol. 1, s. 49-70; D. Rohrbacher, Historians of Late Antiquity, London 2002, 82-92; B. Baldwin, Priscus of Panium, „Byzantion” 50 (1980) 18-61; O. Jurewicz, Historia literatury bizantyńskiej, Wrocław 1984, 27-28; P. Janiszewski, Historiografia późnego antyku, w: Vademecum historyka starożytnej Grecji i Rzymu, t. 3: Źródłoznawstwo czasów późnego antyku, red. E. Wipszycka, Warszawa 1999, 34-36. Fragmenty przełożone na język polski wraz z opisem wyprawy Pryskosa na dwór Attyli można znaleźć w: J. Kuranc, Wyprawa poselstwa wschodnio-rzymskiego na dwór króla Attyli, „Meander” 12 (1956) 20-36.

${ }^{5}$ Do największych osiągnięć Teodozjusza II należą kodyfikacja prawa i założenie uniwersytetu w Konstantynopolu. Por. J.B. Bury, History of the Later Roman Empire. From the Death of Theodosius I to the Death of Justinian, New York 1958, 231-235; E. Stein, Histoire du Bas-Empire, t. 1, éd. française par J.R. Palanque, Paris 1959, 161 i 285-287. Więcej na temat tego władcy i funkcjonowania Imperium za jego rządów, zob. F. Millar, A Greek Roman Empire. Power and Belief under Theodosius II 408-450, Sather Classical Lectures 64, Berkeley 2007.

${ }^{6}$ Por. PLRE II 594-595, s.v. Ioannes 6. Więcej o uzurpacji Jana, oraz późniejszym konflikcie politycznym między wybitymi dowódcami: Flawiuszem Feliksem, Bonifacjuszem i Aecjuszem, prowadzącym do uzyskania dominującej pozycji w państwie przez tego ostatniego, zob. M. Pawlak, Walka o władze w Rzymie w latach 425-435, Toruń 2004. 
może zasiadać na tronie ${ }^{7}$. Bez wątpienia troskę o sprawy Zachodu można także dostrzec w polityce cesarza wobec Wandalów. Problem barbarzyńców, którzy zajęli żyzne ziemie afrykańskie i wyruszali na łupieżcze wyprawy na wybrzeża Imperium, był de facto zagrożeniem dla samego istnienia Cesarstwa na Zachodzie $^{8}$. Wydaje się, że Teodozjusz II doskonale to rozumiał ${ }^{9}$, stąd wysyłane przez niego wyprawy w roku 431 i 441 . Z uwagi na problemy logistyczne oraz kosztów związane z transportem armii morzem, przedsięwzięcia te musiały pochłaniać ogromne środki i angażować znaczną część machiny wojennej Imperium na odległym froncie. Bez wattpienia z punktu widzenia całego Cesarstwa Rzymskiego był on kluczowy, lecz dla samej części wschodniej powstało w tym czasie nowe zagrożenie.

Dotychczasowy władca Hunów, Rugila, był stosunkowo pokojowo nastawiony do Cesarstwa i pobierał niewielki trybut w wysokości 350 funtów złota rocznie $^{10}$. Jednak w 433 lub 434 r. doszło do sporu między nim a Konstantynopolem. Rzymianie pozwalali bowiem na azyl uciekinierom spośród podległych Hunom plemion naddunajskich. Rugila, choć rozwścieczony, chciał rozwiązać sprawę dyplomatycznie, wysyłając swoich posłów i żądając wydania zbiegów. W trakcie negocjacji Rugila zmarł, zaś władzę nad plemionami przejęli synowie jego brata Mundzuka, Attyla i Bleda. Bracia zapoczątkowali ostrzejszą linię polityki wobec Konstantynopola. Postawili dość wygórowane żądania, wykorzystując nieobecność wojsk rzymskich, które były wówczas zaangażowane w kampanię afrykańską. Po negocjacjach w Margos uzyskali od cesarza podwojenie dotychczasowego trybutu, wzajemne wydanie zbiegów i jeńców ${ }^{11}$

\footnotetext{
${ }^{7}$ Por. Pawlak, Walka o władze, s. 82-83.

${ }^{8}$ Do utraty Afryki w wielkim stopniu przyczynił się wspomniany wcześniej konflikt wewnętrzny, zaś zarządzający wojskami prowincji Bonifacjusz był nawet oskarżany o zdradę, por. tamże, s. 144-155; Stein, Histoire du Bas-Empire, t. 1, s. 318-321; J. Strzelczyk, Wandalowie i ich afrykańskie państwo, Warszawa 1992, 121-122.

${ }^{9}$ Por. Thompson, The Foreign Policies, s. 58-75.

${ }^{10}$ Nie wiadomo jednak w jakich okolicznościach, ani też kiedy go otrzymał. Edward A. Thompson (The Foreign Policies, s. 62) sądzi, że władca Hunów uzyskał go w wyniku poselstwa, które przedstawiło Teodozjuszowi II żądania trybutu pod groźbą wojny w 431 roku. Michel Rouche (Attyla i Hunowie. Ekspansja barbarzyńskich nomadów IV-V wiek, thum. J. Jedliński, Warszawa 2011, 81) twierdzi, że Rugila najechał Trację w 422 r., zaś trybut był ceną za wycofanie się i choć faktycznie w tym roku nastąpił najazd Hunów, nie mamy żadnych informacji na temat tego kto nim dowodził. Por. Marcellinus Comes, Chronicon a. 422, ed. B. Croke, w: The Chronicle of Marcellinus, a translation and commentary (with a reproduction of Mommsen's edition of the text) Byzantina Australiensia 7, Sydney 1995, 13. Możliwe też, że władcy Hunów pobierali trybut już od 412 r., kiedy to Olimpiodor bogatymi darami powstrzymał gniew króla Charatona (zob. Olympiodorus, Fragmenta 19, ed. R.C. Blockley, w: The Fragmentary Classicising Historians, vol. 2, s. 182-183) lub też uzyskali go w jakichś okolicznościach w związku z odebraniem im Panonii w 427 r., zob. Marcellinus Comes, Chronicon a. 427, ed. Croke, s. 14.

${ }^{11}$ Także szlachetnych rodem przeciwników politycznych Attyli i Bledy, por. Priscus, Fragmenta 2, ed. Blockley, s. 224-227.
} 
(jednak Rzymianie mieli za swoich zapłacić) oraz utworzenie targów nad Dunajem, z równymi prawami dla huńskich i rzymskich kupców ${ }^{12}$. Te bardzo korzystne postanowienia usatysfakcjonowały Attylę i Bledę, gdyż zwrócili swą uwagę na sprawy wewnętrzne ${ }^{13}$. Możliwe jednak, że obawa przed narastającymi żądaniami barbarzyńców skłoniła Teodozjusza II do odwołania z Afryki wojsk, które prowadziły tam działania przeciw Wandalom ${ }^{14}$.

Nie jest to jedyny przykład sytuacji, gdy Hunowie wykorzystali zaangażowanie sił wschodniorzymskich na odległym od linii Dunaju froncie. W $441 \mathrm{r}$., kiedy siły Cesarstwa prowadziły działania na Sycylii, najechali ziemie trackie, łupiąc je doszczętnie. Najgorszą jednak konsekwencją tego najazdu było kompletne fiasko wielkiej i kosztownej wyprawy przeciw Wandalom, którą trzeba było odwołać wobec ataku barbarzyńców ${ }^{15}$. W taki sposób zagrożenie ze strony Hunów uniemożliwiało Teodozjuszowi II prowadzenie skutecznej polityki zagranicznej. E.A. Thompson przypuszcza, że cesarz liczył na szybkie zwycięstwo nad Wandalami ${ }^{16}$, gdy w tym samym czasie fortyfikacje miast Tracji miałyby powstrzymywać Hunów, aż do czasu powrotu wojsk z Afryki ${ }^{17}$. Jeśli taki był plan władcy, to zakończył się fiaskiem w każdym możliwym aspekcie, gdyż nie tylko nie udało się rozwiązać problemu zagrożenia wandalskiego, lecz co gorsza Hunowie przedarli się przez północną granicę. Cesarz najprawdopodobniej

${ }^{12}$ Por. L.A. Tyszkiewicz, Hunowie w Europie. Ich wpływ na Cesarstwo Wschodnie i Zachodnie oraz na ludy barbarzyńskie, Acta Universitatis Vratislaviensis 2695, Wrocław 2004, 117; I. Bóna, Das Hunnenreich, Stuttgart 1991, 55.

${ }^{13}$ Przede wszystkim zajęci byli walkami z plemionami niegdyś podległymi władzy Rugili, które próbowały wybić się na niezależność po zmianie władzy. Wydaje się, że była to pewna prawidłowość w realiach imperium Hunów, gdzie po śmierci króla jego następca musiał potwierdzić swą zwierzchność nad podbitymi ludami. Była to wielka słabość tego organizmu państwowego, którego spójność opierała się jedynie na strachu przed niepokonanym władcą. Attyla dzięki zapewnieniu swym poddanym bogatych łupów mógł usprawnić ten system, dodając do przysłowiowego „kija” także „marchewkę”. Sprawiało to jednak, że władca był zmuszony prowadzić ciągłe najazdy łupieżcze, by utrzymywać swą aurę niezwyciężoności i stały dopływ złota, por. P. Heather, Upadek Cesarstwa Rzymskiego, tłum. J. Szczepański, Poznań 2006, 424.

${ }^{14}$ Por. Thompson, The Foreign Policies, s. 62.

${ }^{15}$ Pewne znaczenie musiał mieć także wybuch konfliktu na Wschodzie z Persja, jednak atak króla Yazdagarda II okazał się nieskuteczny, por. K. Twardowska, Rzymski Wschód w latach 395518, w: Świat rzymski w V wieku, red. R. Kosiński - K. Twardowska, Kraków 2010, 95; Stein, Histoire du Bas-Empire, t. 1, s. 291.

${ }^{16}$ I faktycznie, wyprawa z 440 r. była przygotowana bardzo sprawnie i szybko, a odpowiedzialny za aprowizację Pentadiusz został za to odpowiednio wynagrodzony, por. PLRE II 858, s.v. Pentadius 2. Jednak podczas niej zrodziły się jakieś spory kompetencyjne, które opóźniły natarcie. Za taki rozwój sytuacji można obarczyć winą samego cesarza, bowiem wojska miały aż trzech dowódców - Ariobindusa, Ansilę i Germanusa (por. Prosper Aquitanus, Epitoma Chronicon 1344, ed. Th. Mommsen, MGH Auctores Antiquissimi IX, Berolini 1892, 478) lub, jeśli przyjąć wersję Teofanesa (Chronographia AM 5941, rec. C. de Boor, Lipsiae 1883, 101), to nawet pięciu, gdyż historyk dodaje do pozostałych Inobindosa i Arintheosa.

${ }^{17}$ Por. Thompson, The Foreign Policies, s. 64-65. 
zawarł z barbarzyńcami porozumienie, jak przypuszcza Otto Maenchen-Helfen, podwajając dotychczasowy trybut ${ }^{18}$.

W $443 \mathrm{r}$. zaczęto prowadzić prace nad umocnieniami na granicy północnej. Cesarz wyraźnie szykował się do konfrontacji ${ }^{19}$. Napięcie rosło także w relacjach między Hunami a Cesarstwem Zachodnim, i aż do zawarcia pokoju przez Aecjusza, istniało realne zagrożenie wojną ${ }^{20}$. Wtedy, być może powodowany solidarnością wobec Walentyniana III, lub wykorzystując fakt, że uwaga Hunów była skupiona gdzie indziej, Teodozjusz II zaniechał wysyłania trybutu. W jego decyzji mogły utwierdzić go doniesienia o konflikcie między Bledą i Attyla, w wyniku którego ten pierwszy został zamordowany, zaś drugi przejął pełnię władzy ${ }^{21}$. Póki Attyla był zajęty innymi sprawami, na północnej granicy panował spokój. Jednak barbarzyńca bynajmniej nie zapomniał wyrządzonego mu afrontu, a ponadto potrzebował stałego dopływu złota, by utrzymywać swych ludzi w ryzach, o czym poinformował listownie Teodozjusza ${ }^{22}$. Cesarz nie zareagował. Być może poczuł się zbyt bezpiecznie i ponownie nie potrafił trafnie ocenić sytuacji, przez co spowodował najtragiczniejszy w skutkach najazd na tereny Imperium. W 447 r. wojska rzymskie pod wodzą Arnegisklosa zostały rozbite nad rzeką Utus ${ }^{23}$, zaś hordy Hunów rozlały się po całej Tracji ${ }^{24}$.

${ }^{18}$ Por. O. Maenchen-Helfen, The World of Huns. Studies in Their History and Culture, Berkeley 1973, 117.

${ }^{19}$ Por. Heather, Upadek Cesarstwa Rzymskiego, s. 359.

${ }^{20}$ Przyjmuję tu interpretację Otto Maenchena-Helfena (The World of Huns, s. 95-107). Zob. też M. Pawlak, Aecjusz i barbarzyńcy, Mediterraneum 5, Kraków 2007, 233-236. Trzeba natomiast zauważyć, że większość badaczy przyjmuje, że ów układ pokojowy, datowany w powyższej interpretacji na lata 40., Aecjusz zawarł z królem Rugą mniej więcej dekadę wcześniej i że wiązał się on z przekazaniem Hunom części Panonii. O dyskusji w historiografii na ten temat zob. H. Gračanin, The Huns and South Pannonia, „Byzantinoslavica” 64 (2006) 50-53.

${ }^{21}$ Miał on miejsce na przełomie lat 444-445. Por. Heather, Upadek Cesarstwa Rzymskiego, s. 359; Bóna, Das Hunnenreich, s. 62.

${ }^{22}$ Por. Priscus, Fragmenta 9, ed. Blockley, s. 234-235. O interpretacji tego fragmentu zob. Maenchen-Helfen, The World of Huns, s. 118.

${ }^{23}$ Por. Marcellinus Comes, Chronicon a. 447, ed. Croke, s. 19. Teofanes (Chronographia AM 5942, rec. de Boor, s. 102) wymienia obok Arnegisklosa także Aspara i Ariobindusa, nie wiadomo jednak jaka była ich rola w kampanii z 447 roku. Być może dowodzili innymi kontyngentami lub brali udział w walkach nad Utus i zdołali się wycofać. Warto zaznaczyć, że Hunowie ponieśli w walkach z regularną armią rzymską spore straty, zob. E.A. Thompson, Hunowie, oprac. P. Heather, thum. B. Malarecka, Warszawa 2015, 83.

${ }^{24}$ Dla wydarzeń z lat 441-447 przyjmuję chronologię i interpretację źródeł autorstwa Otto Maenchen-Helfena (The World of Huns, s. 113-127), jako najbardziej spójną. Zakłada ona, że Teofanes (Chronographia AM 5942, rec. de Boor, s. 102-103), przedstawiając przebieg konfliktu, streszcza $\mathrm{w}$ jednym ustępie wydarzenia z kilku lat, zaś opis porażki w walkach z Hunami dotyczy najazdu z 447 roku. Inną interpretację zaproponował Edward A. Thompson (Hunowie, s. 200), który twierdził, że zaległy trybut pochodził jeszcze od czasów układu w Margos. Argumentacja Otto Maenchen-Helfena jest jednak bardziej przekonywająca, gdyż wyjaśnia czemu cesarz poczuł się pewniej i zrezygnował z wypłaty trybutu. Fałszywe poczucie bezpieczeństwa wywołało zwrócenie przez Hunów oczu na Zachód, zaś w dalszym biegu wypadków, konflikt wewnętrzny między braćmi Attylą i Bledą. 
Straty były ogromne, o czym informuje nas Pryskos, mający okazję podziwiać dzieło zniszczenia w drodze na dwór Attyli ${ }^{25}$.

Cesarz został zmuszony do ponownego płacenia trybutu, tym razem trzykrotnie większego niż ustalony ponad dekadę wcześniej w Margos, oraz do uiszczenia zaległych opłat w wysokości 6000 funtów złota. Sumy te nie są paradoksalnie zbyt imponujące, jeśli weźmiemy pod uwagę możliwości finansowe całego państwa, lecz trzeba pamiętać, że w przypadku, gdy jedna z prowincji była kompletnie spustoszona i należało natychmiast znaleźć środki na załatanie „dziury” budżetowej, nawet takie sumy mogły stanowić problem. Aby wywiązać się z postanowień porozumienia z Hunami trzeba było nałożyć dodatkowe, bardzo uciążliwe dla ludności podatki ${ }^{26}$. To jednak nie koniec szeregu nieszczęść, jakie zostały spowodowane przez najazd z 447 roku. Jednym $\mathrm{z}$ warunków pokoju było utworzenie strefy ziemi niczyjej na 5 dni drogi po południowej stronie Dunaju ${ }^{27}$. By w pełni zdać sobie sprawę z powagi sytuacji należy zauważyć, że te ustalenia pozbawiały Cesarstwo kontroli nad twierdzami limesu północnego, opartymi o naturalną granicę, z całym szeregiem systemów jej zabezpieczenia, takimi jak np. patrolująca bieg Dunaju flota. Po 447 r. trackie prowincje Imperium były zatem na łasce Attyli i jego hord, który w każdej chwili mógł je najechać, nie przebijając się przez żadne umocnienia. Na szczęście dla Rzymian władca Hunów chyba nie był zainteresowany samymi ziemiami, a raczej wojownikami i złotem ${ }^{28}$, o czym świadczy fakt, że Attyla zgodził się w 450 r. wycofać za Dunaj po negocjacjach prowadzonych z poselstwem Anatoliusza i Nomusa ${ }^{29}$.

W takiej sytuacji trudno się dziwić, że polityka zewnętrzna Teodozjusza II jest w źródłach oceniana bardzo negatywnie. Współodpowiedzialnością za nią obarcza się także współpracowników cesarza, zwłaszcza prepozyta świętej sypialni, eunucha Chryzafiusza, który na początku lat czterdziestych miał wywierać wielki wpływ na władcę ${ }^{30}$. Poza tym sama postać eunucha jest w źródłach ukazywana w bardzo negatywnym świetle ${ }^{31}$. W przypadku polityki

${ }^{25}$ Por. Priscus, Fragmenta 11, ed. Blockley, s. 242-249.

${ }^{26}$ Choć opis Pryskosa jest zapewne przesadzony, to nagłość i gorliwość, z jaką musiały być zebrane, z pewnością mogły przysporzyć wiele krzywd poddanym cesarza, por. C.D. Gordon, The Age of Attila. Fifth-Century Byzantium and the Barbarians, Ann Arbor Paperback 111, Ann Arbor 1962, 66-67; Maenchen-Helfen, The World of Huns, s. 114.

${ }^{27}$ Por. Maenchen-Helfen, The World of Huns, 124; Hohlfelder, Marcian's Gamble, s. 55.

${ }^{28}$ Plemion barbarzyńskich mogących stanowić zaplecze militarne dla Attyli na tych terenach nie było, zaś ze złota zostały już ogołocone.

${ }^{29}$ Por. Priscus, Fragmenta 15, ed. Blockley, s. 298-299. Zatem jak zauważa Fergus Millar (A Greek Roman Empire, s. 82-83), granice Imperium mimo zawirowań politycznych zostały ostatecznie nienaruszone. Nie zmienia to faktu, że choć w 450 r. na południe od Dunaju nie było już wojowników huńskich, to cały system umocnień nadal leżał w gruzach.

${ }^{30}$ Por. Theophanes, Chronographia AM 5941, rec. de Boor, s. 101; Bury, History of the Later Roman Empire, s. 235.

${ }^{31}$ Por. Priscus, Fragmenta 15, ed. Blockley, s. 300-301. Ponadto był chciwy i odpowiedzialny 
zewnętrznej znamy jeden przykład działania, na które Chryzafiusz na pewno miał bezpośredni wpływ. Była to próba zabójstwa Attyli w 449 roku $^{32}$. Przedsięwzięcie nie powiodło się, zaś władca Hunów dowiedział się o całej sprawie i choć w gniewie zażądał nawet wydania mu eunucha, ostatecznie został ułagodzony przez poselstwo Anatoliusza i Nomusa. Znając przebieg wydarzeń, które spowodowała śmierć Attyli w 453 r., można przypuszczać, że powodzenie spisku wiązałoby się ze znacznymi korzyściami dla Rzymian. Nie można zatem odmówić Chryzafiuszowi sprytu i znajomości słabości wroga.

Teodozjusz II z pewnością posiadał własną wizję polityki zewnętrznej. Zależało mu na utrzymaniu bliskich relacji i wzajemnej zależności między obiema częściami Imperium, a także należy docenić zrozumienie przez niego powagi zagrożenia ze strony Wandalów. W przypadku polityki wobec Hunów Teodozjusz II popełnił wiele błędów. Z drugiej zaś strony trzeba wziąć pod uwagę kwestie, na które nie miał on wpływu, jak np. porażki militarne swych dowódców, czy trzęsienie ziemi w roku $447^{33}$, które na pewno utrudniło obronę przed barbarzyńcami. Generalnie jednak w działaniach Teodozjusza II wobec Hunów nie widać jasnej koncepcji. Cesarz lawirował między polityką ugodową, wręcz uległa, a zrywaniem porozumień i dążeniem do konfrontacji. Bilans tych działań był dla Imperium katastrofalny, a porażki na Bałkanach wpływały także na niepowodzenia innych przedsięwzięć władcy, przede wszystkim wypraw przeciw Wandalom.

2. Objęcie tronu przez Marcjana. Nagła śmierć Teodozjusza II pogłębiła jeszcze trudną sytuację geopolityczną. Do istniejących problemów doszedł nowy. Cesarz nie posiadał męskiego potomka, ani nie wyznaczył wcześniej współrządcy, a zatem Walentynian III, będąc mężem Licynii Eudoksji, córki Teodozjusza II, powinien objąć władzę nad obiema częściami Cesarstwa lub wyznaczyć następcę ${ }^{34}$. Wydaje się jednak, że na Wschodzie taka perspektywa nie cieszyła się popularnością. Podział dokonany w 395 r. zdążył już ugruntować się w świadomości mieszkańców. Na niekorzyść Walentyniana przemawiały także jego osiagnięcia, pozostawał on bowiem ciagle w cieniu swego

za zepsucie Teodozjusza II, co było przyczyną wielu nieszczęść Rzymian, zob. tamże 3, ed. Blockley, s. 226-229; Ioannes Malalas, Chronographia XIV 19, rec. J. Thurn, CFHB Series Berolinensis 35, Berolini et Novi Eboraci 2000, 283.

${ }^{32}$ Por. Priscus, Fragmenta 11, ed. Blockley, s. 244-247. O jej przebiegu informuje Pryskos, który miał okazję być członkiem poselstwa, w skład którego wchodzili opłaceni przez Chryzafiusza zabójcy. Sam historyk o całej sprawie nie wiedział i zapewne fakt, że powodzenie jego misji, a także osobiste bezpieczeństwo zostały wystawione na szwank, wpłynęły na jego ocenę tego wydarzenia.

${ }^{33}$ Por. M.B. Leszka - M.J. Leszka, Zarys dziejów Konstantynopola w latach 337-602, w: Konstantynopol - Nowy Rzym. Miasto i ludzie w okresie wczesnobizantyńskim, red. T. Wolińska M.J. Leszka, Warszawa 2011, 71.

${ }^{34}$ Por. Bury, History of the Later Roman Empire, s. 235; Stein, Histoire du Bas-Empire, t. 1, s. 311; R.W. Burgess, The Accession of Marcian in the Light of Chalcedonian Apologetic and Monophysite Polemic, ByZ 86-87 (1993/1994) 63. 
potężnego magistra militum Aecjusza. W tej sytuacji w miesiąc po śmierci Teodozjusza na tron w Konstantynopolu wstapił Marcjan.

O przeszłości tego człowieka mamy niewiele dokładnych informacji. Marcjan najprawdopodobniej pochodził z Tracji, z rodziny o tradycjach wojskowych i sam również podążył ścieżką kariery w armii ${ }^{35}$. W latach 421-422 miał wyruszyć na wojnę z Persami dowodząc oddziałem wojska, i choć Teofanes określa go mianem „,Zwykłego żołnierza" ${ }^{36}$, prawdopodobnie dzierżył rangę tribunus $^{37}$. Marcjan jednak nie dotarł na front, gdyż zachorował w drodze i powrócił do Konstantynopola, gdzie miał podjąć służbę pod komendą Aspara w randze domesticus.

Wziął też udział w nieudanej kampanii afrykańskiej przeciw Wandalom, gdzie dostał się do niewoli. Tam, jak podaje Prokopiusz, miała uratować go dobra wróżba. Kiedy bowiem Marcjan spał, nad miejscem jego spoczynku orzeł zataczał kręgi tak, że swym cieniem osłonił śpiącego. Wandalowie uznali to za znak losu, iż Marcjan zostanie wkrótce cesarzem, wobec czego Gejzeryk zdecydował się wypuścić Rzymianina, jeśli ten złoży przysięgę, że nigdy nie wyprawi się przeciw jego królestwu ${ }^{38}$. Przywołany fragment $\mathrm{z}$ Historii wojen jest oczywiście mało wiarygodny, zwłaszcza że nie jest to jedyna zachowana w źródłach przepowiednia mająca pokazać, iż cesarska purpura była Marcjanowi przeznaczona.

Ewagriusz przywołuje za Pryskosem, że w swej młodości Marcjan podróżował do Filipopola, by zaciagnąć się do wojska, lecz po drodze znalazł ciało zabitego żołnierza, którego zdecydował się godnie pochować. Niestety ktoś to zauważył i doniósł władzom, przez co Marcjana niesłusznie oskarżono o morderstwo. Jednak w wyniku boskiej interwencji prawdziwy sprawca został ujawniony, dzięki czemu Marcjan mógł zaciagnąć się do wojska. Z uwagi na swoje zalety, został wpisany na miejsce niedawno zabitego żołnierza, któremu na imię było Augustus, co odpowiadało także tytulaturze rządzących Imperium i miało - zdaniem źródła - zwiastować Marcjanowi jego cesarską przyszłośćc ${ }^{39}$.

Podobna sytuacja jak w Afryce, miała miejsce wcześniej w Licji, gdy Marcjana dopadła choroba, w trakcie drogi na wojnę z Persami. Cień orła krążącego nad spoczywającym Marcjanem zauważyli jego przyjaciele, którzy zinterpretowali ten omen identycznie jak Wandalowie. Wymogli na nim przysięgę, że odwdzięczy się im po uzyskaniu cesarskiej purpury. Gdy ten - zaskoczony

\footnotetext{
${ }^{35}$ Por. Priscus, Fragmenta 18, ed. Blockley, s. 302-305.

${ }^{36}$ Theophanes, Chronographia AM 5943, rec. de Boor, s. 104.

${ }^{37}$ Jan Malalas (Chronographia XIV 27, CFHB Series Berolinensis 35, s. 288) wspomina bowiem, że sprawował wcześniej tę funkcję, zapewne miało to miejsce w trakcie wspomnianych wydarzeń.

${ }^{38}$ Procopius Caesariensis, De bellis libri III 4, 2-10, rec. J. Havry, addenda et corrigenda adiecit G. Wirth,, w: Procopii Caesariensis Opera omnia, vol. 1, Lipsiae 1962, 324, 21 - 326, 4, thum. D. Brodka: Historia wojen, t. 1: Wojny z Persami i Wandalami, Źródła Historyczne, Kraków 2013, 215-216.

${ }^{39}$ Por. Priscus, Fragmenta 18, ed. Blockley, s. 302-305. Zob. Evagrius Scholasticus, HE II 1, PG 86, 2485D i 2488B, tłum. S. Kazikowski: Ewagriusz Scholastyk, Historia Kościoła, Warszawa $1990,43-44$.
} 
- przystał na to, dali mu pieniądze i wysłali do Konstantynopola. Po objęciu tronu Marcjan naturalnie słowa dotrzyma ${ }^{40}$. Te przekazy dostarczają nam bezcennych informacji na temat wczesnej kariery władcy, lecz trzeba pamiętać, że są zapewne mocno podkoloryzowane. Wynikają prawdopodobnie z linii propagandy cesarskiej, lansowanej przez dwór i popleczników cesarza, a zwłaszcza zwolenników jego polityki religijnej ${ }^{41}$. Fragmenty te mają za zadanie przekonać odbiorcę, iż Marcjan zawdzięczał władzę swym zaletom i przeznaczeniu, oraz że wykazywał się pozytywnymi cechami, takimi jak pobożność czy pamięć o przyjaciołach.

Po wyeliminowaniu elementów niewiarygodnych, kariera Marcjana jawi się jako bardzo przeciętna. Był on jednym $\mathrm{z}$ wielu dowódców niższego szczebla, nie pochodził z wybitnego rodu, a jedynym czynnikiem, jaki go wyróżniał, były bliskie relacje z potężnym Flawiuszem Ardaburiuszem Asparem ${ }^{42}$. Można powiedzieć, że sama liczba przekazów mówiących o cesarskim przeznaczeniu Marcjana, wskazuje na to, iż poza wspomnianym nieuchwytnym uśmiechem losu, nic innego nie predestynowało go do purpury. Rzeczywiście wydaje się, że został cesarzem w wyniku zawirowań politycznych, jakie miały miejsce po śmierci Teodozjusza II, zaś Marcjan był po prostu kandydatem pewnego stronnictwa politycznego, które możemy utożsamiać ze wschodniorzymską arystokracją wojskową, na czele której najprawdopodobniej stał Aspar i Flawiusz Zenon. Przypuszczalnie jednym z powodów, dla których zdecydowali się forsować własnego kandydata na tron ${ }^{43}$, było zniesmaczenie dotychczasową polityką zewnętrzną. Jako dowódcy wojskowi to oni właśnie ponosili szkodę w związku z fiaskiem dyplomacji Chryzafiusza, prowadzącej do starć nieprzygotowanych Rzymian z Hunami. Sam Zenon zresztą otwarcie sprzeciwiał się działaniom eunucha i, jak informuje nas Pryskos, istniała realna obawa na dworze konstantynopolitańskim przed jego otwartym buntem ${ }^{44}$. Obaj wodzowie mogli liczyć na wsparcie Pulcherii, siostry Teodozjusza, która

${ }^{40}$ Por. Theophanes, Chronographia AM 5943, rec. de Boor, s. 104-105.

${ }^{41}$ Por. Burgess, The Accession of Marcian, s. 59. Dariusz Brodka (Priskos von Panion und Kaiser Marcian. Eine Quellenuntersuchung zu Procop. 3,4,1-11, Evagr. HE 2,1, Theoph. AM 5943 und Nic. Kall. HE 15,1, „Millenium” 9 (2012) 159) twierdzi, że te anegdoty musiały zostać przekazane za pośrednictwem innego źródła niż Historia Pryskosa, gdyż - jego zdaniem - historyk unikał wprowadzania elementów związanych z wpływem Boskiej Opatrzności w swym dziele.

${ }^{42}$ Służył najpierw u jego ojca Ardabura, potem zaś u samego Aspara, łącznie 15 lat. Por. Theophanes, Chronographia AM 5943, rec. de Boor, s. 104-105.

${ }^{43}$ Sami objąć władzy nie mogli przede wszystkim ze względów religijnych. Zenon był poganinem, zaś tron cesarstwa był dostępny wyłącznie dla chrześcijan, por. M.J. Leszka, Uzurpacje w Cesarstwie Bizantyńskim w okresie od IV do połowy IX wieku, Byzantina Lodziensia 4, Łódź 1999, 15. Aspar wyznawał herezję ariańską, co również stanowiło pewien problem. Można jednak się zastanawiać, czy chcieli obejmować władzę. Sprawowanie rządów w cieniu tronu mogło być wygodniejsze, o czym świadczy fakt, że sam Aspar odmówił, gdy 7 lat później senat prosił go o objęcie tronu, por. Acta synodorum habitarum Romae 5, 23-26, ed. T. Mommsen, MGH Auctores Antiquissimi XII, Berolini 1894, 425.

${ }^{44}$ Por. Priscus, Fragmenta 16, ed. Blockley, s. 300-301. 
była zawziętą przeciwniczką Chryzafiusza, głównie ze względów religijnych ${ }^{45}$. W takiej sytuacji potrzebny był kandydat na władcę, który z jednej strony powinien być związany ze stronnictwem przeciwnym eunuchowi, z drugiej zaś nie nazbyt potężny, aby nie zaczął forsować własnej niezależnej polityki.

Marcjan wydawał się idealnym rozwiązaniem. Swą władzę zawdzięczał wyłącznie wsparciu potężnych wodzów ${ }^{46}$. Jego rządy zostały zalegalizowane poprzez małżeństwo z ponad 50-letnią wówczas Pulcherią, która złożyła wcześniej śluby wiecznego dziewictwa. Związek z Marcjanem był, jak twierdzi Richard Burgess, wyłącznie formalny i zapewne nawet nieskonsumowany ${ }^{47}$. Było to o tyle wygodne dla jego benefaktorów, iż ze względu na postanowienia Pulcherii oraz jej zaawansowany wiek, nie było w zasadzie żadnych szans na dziedzica tronu. W takiej sytuacji naiwnością byłoby przypuszczenie, że polityka Marcjana była całkiem samodzielna ${ }^{48}$. Cesarz musiał brać pod uwage słabość swego zaplecza. Mimo to władca ten nie był marionetką w rękach swego byłego przełożonego, biorąc pod uwagę pozytywny obraz Marcjana w narracji Pryskosa, który za Asparem raczej nie przepada ${ }^{49}$ i na pewno zwróciłby uwagę na to, że cesarz nie był samodzielny w swych decyzjach ${ }^{50}$. Wódz bez wątpienia wywierał presję na władcę ${ }^{51}$, natomiast zastanawiające jest, iż Aspar prawie nie pojawia się w źródłach za czasów Marcjana, co może wskazywać na to, że nie występowały między nimi konflikty ${ }^{52}$. Władca realizował

${ }^{45}$ Chryzafiusz był bowiem monofizytą, zaś Pulcheria zagorzałą zwolenniczką ortodoksji. Duże znaczenie miało też to, że Chryzafiusz był odpowiedzialny za odsunięcie Pulcherii od władzy w 441 r., por. Holum, Theodosian Empresses, s. 191-192.

${ }^{46}$ Wedle świadectwa Jana Malalasa (Chronographia XIV 26-27, CFHB Series Berolinensis 35, s. 288) oraz niemal identycznego przekazu w Kronice Wielkanocnej (Chronicon Paschale a. 450, rec. L. Dindorf, Bonnae 1832, 590) Marcjana miał na łożu śmierci wybrać sam Teodozjusz II, w obecności Aspara i senatorów. Z drugiej strony Teofanes (Chronographia AM 5942, rec. de Boor, s. $102-$ 103), Hydacjusz (Chronica Subdita 139, ed. with an English translation by R.W. Burgess, w: The Chronicle of Hydatius and Consularia Constantinopolitana, two contemporary accounts of the final years of the Roman Empire, Oxford Classical Monographs, Oxford 1993, 101) i Ewagriusz (HE II 1, PG 86, 2489B) stwierdzaja, że Marcjan zawdzięczał tron wstawiennictwu Pulcherii. Jednak R.W. Burgess (The Accession of Marcian, s. 61-63) dostarcza przekonywujących argumentów na to, że ani Teodozjusz, ani Pulcheria nie mieli decydującego głosu przy wyborze Marcjana na cesarza.

${ }^{47}$ Por. Holum, Theodosian Empresses, s. 209; Burgess, The Accession of Marcian, s. 67.

${ }^{48}$ Analizując wpływy Aspara trzeba także pamiętać o zapleczu militarnym jakie posiadał m.in. poprzez swoje relacje z rodziną Plinty (najpewniej ożenił się z jego córką), przez co mógł liczyć na kilka tysięcy gockich foederati poza wojskami, które przysługiwały mu z racji pełnionych pozycji, por. A. Urbaniec, Wpływ patrycjusza Aspara na cesarskq elekcję Leona, „U Schyłku Starożytności. Studia Źródłoznawcze" 11 (2011) 188-189.

${ }^{49}$ To od Pryskosa (Fragmenta 53, ed. Blockley, s. 364-365) pochodzą oskarżenia wobec Aspara o zdradę w związku z wyprawą Bazyliskosa.

${ }^{50}$ Zwłaszcza, że jest to jeden z jego głównych zarzutów wobec Teodozjusza II.

${ }^{51}$ Por. W.E. Kaegi, Byzantium and the Decline of Rome, Princeton 1968, 30.

${ }^{52}$ Dla kontrastu konflikt między Asparem a następcą Marcjana, Leonem, stanowi istotny element narracji późnoantycznych dziejopisarzy. Przykładowo, zob. Candidus, Fragmenta 1, 25-41, ed. R.C. Blockley, w: The Fragmentary Classicising Historians, vol. 2, s. 464-467; Priscus, Fragmenta 
swą politykę w oparciu o koncepcje Aspara, przez co ten nie miał potrzeby interweniować. Być może poglądy cesarza i jego wodza na politykę zewnętrzną państwa były zbieżne. Trzeba pamiętać, że Marcjan także był wojskowym oraz pochodził z północnych prowincji, które najbardziej ucierpiały w związku z najazdami Hunów. Nie można również wykluczyć, że po piętnastu latach służby jako domesticus wodza, Marcjan i Aspar zaprzyjaźnili się, co położyło fundamenty pod późniejszą współpracę polityczną.

Warto zatem przyjrzeć się dokładniej postaci Aspara. Pochodził on z plemienia Alanów, a jego ojcem był doświadczony wódz, Flawiusz Ardabur. Swe pierwsze szlify wojskowe Aspar zdobywał we wczesnej młodości ${ }^{53}$, prawdopodobnie u jego boku. W 424 r. razem brali udział w wyprawie przeciw uzurpatorowi Janowi. Aspar już na tym etapie samodzielnie dowodził częścią sił ${ }^{54}$, a wkrótce objął faktyczne dowództwo nad całą armią, ze względu na fakt, iż przeprawiający się morzem Ardabur wpadł w wyniku złej pogody w ręce Jana. Mimo to syn wodza stanął na wysokości zadania i kontynuował kampanię, oblegając uzurpatora w Rawennie i ostatecznie pokonując. To jednak nie był koniec działalności Aspara w Italii, bowiem na pomoc Janowi przybył Aecjusz z najemnikami huńskimi, z którym młody wódz starł się w krwawej bitwie, jednak jej wynik pozostał nierozstrzygnięty ${ }^{55}$.

W 431 r. Aspar został ponownie wysłany na Zachód, tym razem już jako głównodowodzący. Celem wyprawy była zagrożona przez Wandalów Afryka. Tym razem jednak przeciwnik okazał się zbyt silny. Wojsko Aspara zostało pobite, a do niewoli dostało się wielu Rzymian, w tym późniejszy cesarz Marcjan, natomiast sam Aspar z niedobitkami był zmuszony wycofać się do Kartaginy ${ }^{56}$. Tam pozostawał przynajmniej do 434 r. ${ }^{57}$, prawdopodobnie zarzą-

53, ed. Blockley, s. 364-365; Procopius Caesariensis, De bellis III 6, 2-4, rec. Havry - Wirth, vol. 1, s. 335-336, thum. Brodka, t. 1, s. 222-223; Theophanes, Chronographia AM 5962-64, rec. de Boor, s. 116-118; Evagrius Scholasticus, HE II 16, PG 86, 2544B i 2545A. O jego przebiegu, zob. B. Croke, Dynasty and Ethnicity. Emperor Leo I and the Eclipse of Aspar, „Chiron” 35 (2005) 147-203.

${ }^{53}$ Por. Candidus, Fragmenta 1, 4-5, ed. R.C. Blockley, w: The Fragmentary Classicising Historians, vol. 2, s. 464-465.

${ }^{54}$ Por. Philostorgius, HE XII 13, ed. J. Bidez, bearb. F. Winkelmann, w: Philostorgius, Kirchengeschichte, mit dem Leben des Lucian von Antiochien und den Fragmenten eines arianischen Historiographen, GCS 21, Berlin 1972², 148-149. Aspar dowodził jazdą, podczas gdy Ardabur przeprawiał się drogą morską. Trudno określić czy Aspar był wyznaczony samodzielnym dowódcą na stałe, czy też objął on tymczasowo dowództwo nad jazdą ze względu na trudność w transporcie koni.

${ }^{55}$ Por. tamże XII 14, GCS 21, 149-150. Marcin Pawlak (Walka o władzę, s. 81) sądzi, że była to niewielka potyczka, po której doszło do porozumienia między wodzami. Przyczyną takiego stanu rzeczy miało być to, iż Aecjusz chciał jedynie dać pokaz siły wobec Galli Placydii, by ta obawiała się ukarać go za wsparcie uzurpatora. Asparowi zależało zaś na szybkim zakończeniu kampanii i triumfalnym powrocie na Wschód.

${ }^{56}$ Marek Wilczyński (Zagraniczna i wewnętrzna polityka afrykańskiego państwa Wandalów, Prace Monograficzne Wyższej Szkoły Pedagogicznej w Krakowie 176, Kraków 1994, 44-45) jest sceptyczny, czy do bitwy rzeczywiście doszło.

${ }^{57}$ Por. Strzelczyk, Wandalowie i ich afrykańskie państwo, s. 130. 
dzając miastem i broniąc go przed ewentualnym atakiem Wandalów. W $442 \mathrm{r}$. brał udział w negocjacjach rozejmu po katastrofalnym dla Cesarstwa najeździe Hunów ${ }^{58}$, a po jego wygaśnięciu uczestniczył w walkach przeciwko Attyli, jednak z mizernym skutkiem.

Udział Aspara w niezbyt udanych kampaniach Teodozjusza musiał wpłynać na jego podejście do interwencji Konstantynopola na Zachodzie. Wydaje się, że preferował ostrożność w działaniach dyplomatycznych. Przejawia się to wyraźnie w jego późniejszym konflikcie z cesarzem Leonem, kiedy Aspar miał sprzeciwiać się angażowaniu środków przeciw Wandalom lub wtrącaniu się w konflikty między barbarzyńcami ${ }^{59}$.

We wczesnym okresie panowania Marcjana niewątpliwie ważną rolę odgrywał fakt, iż Walentynian III nie uznawał jego władzy aż do roku 452. Można zatem przypuszczać, że cesarz nie kwapił się do angażowania sił i środków na rzecz swego przeciwnika politycznego ${ }^{60}$.

3. Marcjan wobec zagrożenia ze strony Hunów. Pierwszym kryzysem, który nastąpił za panowania Marcjana był najazd Hunów na Galię w 451 roku. Zastanawiające jest, czemu władca Hunów zdecydował się obrać taki właśnie kierunek uderzenia. Choć stosunki między Attylą a Rawenną były napięte ze względu na spór o złote misy ${ }^{61}$ oraz niespełnione żądanie oddania królowi Honorii, siostry Walentyniana III, za żonę ${ }^{62}$, to jednak Konstantynopol nie

${ }^{58}$ Miał on miejsce pod nieobecność większości armii, która była związana na Sycylii w kampanii przeciw Wandalom od 440 roku. Edward A. Thompson (The Foreign Policies, s. 64) przypuszcza, że Aspar dowodził i tą wyprawą, ze względu na jego doświadczenie w walkach w Afryce, natomiast nie ma na to dowodów w źródłach. Por. Prosper Aquitanus, Epitoma Chronicon 1344, MGH Auctores Antiquissimi IX 478; Theophanes, Chronographia AM 5941, rec. de Boor, s. 101. George Vernadsky (Flavius Ardabur Aspar, „Südost-Forschungen” 6 (1941) 47-48) przypuszcza, że Aspar odmówił dowodzenia w tej wyprawie, gdyż jego zdaniem miał w czasie kampanii w latach 431-434 razem z Marcjanem obiecać Gejzerykowi, że nie wyruszy przeciw Wandalom i Alanom. Bardziej prawdopodobne wydaje się jednak, że Teodozjusz po prostu starał się nie polegać zbytnio na jednym wodzu.

${ }^{59}$ Dotyczyło to konfliktu Gotów ze Skirami, w którym Aspar zalecał zachować neutralność, zaś Leon wbrew jego radom zdecydował się pomóc Skirom, por. Priscus, Fragmenta 45, ed. Blockley, s. 352-353.

${ }^{60} \mathrm{Nie}$ był to z pewnością powód kluczowy, bowiem Marcjan nie zmienił swej polityki w momencie, gdy jego władzę zaakceptowano na Zachodzie.

${ }^{61}$ Por. tamże 11, ed. Blockley, s. 262-265. Zob. też Heather, Upadek Cesarstwa Rzymskiego, s. 390; H. Gračanin, The Western Roman Embassy to the Court of Attila in A.D. 449, „Byzantinoslavica" 61 (2003) 60-61.

${ }^{62}$ Por. Gračanin, The Western Roman Embassy to the Court of Attila in A.D. 449,, s. 64-67. Trudno określić jaką rzeczywiście rolę pełniła w całym konflikcie Honoria. Attyla miał ponoć oczekiwać praw do połowy Cesarstwa poprzez to małżeństwo, ale trudno stwierdzić, czy jest to wynik udramatyzowanej narracji prowadzonej przez autorów antycznych, czy fakt niezrozumienia przez Attylę realiów rzymskich, bowiem wśród Hunów kobiety odgrywały większą rolę polityczną, często ciesząc się sporą niezależnością, zob. Rouche, Attyla i Hunowie, s. 172-178. Faktem jest, że 
mógł poszczycić się lepszymi ${ }^{63}$, biorąc pod uwagę próbę morderstwa na Attyli ledwie rok wcześniej oraz zaprzestanie płacenia trybutu przez Marcja$n^{64}$. Prawdopodobnie nowy cesarz, sam mając doświadczenie militarne oraz związki z bizantyńskim stronnictwem wojskowym, umocnił zawczasu granicę północną ${ }^{65}$. Innym powodem, który mógł wpłynąć na decyzję Attyli, było wyniszczenie ziem trackich po najeździe z 447 roku. Atak na wschodnią część cesarstwa byłby zatem nie tylko trudniejszy, ale także mniej dochodowy ${ }^{66}$. To prawdopodobnie skłoniło Hunów do wybrania łatwiejszego przeciwnika ${ }^{67}$.

Władca Hunów wysłał część swych oddziałów, by spustoszyły Trację, co zdaniem Michela Rouche, miało zatrzymać nadejście posiłków ze Wschodu ${ }^{68}$. Można się jednak zastanawiać, czy rzeczywiście Marcjan planował wysyłanie swych wojsk w obronie sąsiada, i to do odległej galijskiej prowincji. Biorąc z kolei pod uwagę ilość i jakość wojsk potrzebnych Attyli do prowadzenia wojny przeciw Cesarstwu na Zachodzie, należy przypuszczać, że władca Hunów z pewnością nie mógł wysłać zbyt dużej części swych sił do najazdu na Trację. Choć taka wycieczka była zapewne uciążliwa, przede wszystkim ze względu na mobilność barbarzyńców, nie mogła ona jednak związać większości sił wschodniorzymskich. Możliwe, że istniała pewna obawa przed zmasowanym najazdem ${ }^{69}$, stąd sama obecność cesarza w Tracji, jednakże stopień przygotowania Aecjusza na atak Hunów oraz listy papieża Leona, które

doszło nawet do sporu między Teodozjuszem, który nalegał by ustapić Attyli i wysłać Honorię do niego, a Walentynianem, który trzymał siostrę w areszcie domowym, zob. Priscus, Fragmenta 17, ed. Blockley, s. 300-303. Więcej interpretacji na temat tej sprawy proponuje Marcin Pawlak (Aecjusz i barbarzyńcy, s. 242-248).

${ }^{63}$ Niewątpliwie nastapiła pewna odwilż pod sam koniec panowania Teodozjusza II, o czym świadczy ciepłe przyjęcie posłów Anatoliusza i Nomusa przez Attylę.

${ }^{64}$ Marcin Pawlak (Aecjusz i barbarzyńcy, s. 249) twierdzi, że w ten sposób Marcjan wręcz zachęcał Hunów do ataku na Zachód, bowiem przy odmowie zapłaty trybutu zaznaczył, że Attyla otrzyma pewne dary, jeśli tylko powstrzyma się przed najazdem na ziemie Cesarstwa Wschodniego.

${ }^{65}$ Ponadto po ciężkiej bitwie nad Utus Attyla mógł obawiać się ponownego starcia z regularną armią rzymska, por. Thompson, Hunowie, s. 170-171.

${ }^{66}$ Trzeba pamiętać, że Attyla potrzebował ciągłego dopływu bogactw. Marcin Pawlak (Aecjusz i barbarzyńcy, s. 253) przypuszcza, że Attyla atakując Galię chciał także podporządkować sobie zamieszkujące ją plemiona Gotów. Prawdopodobnie początkowo chciał w ogóle uniknąć walki z Rzymianami, a wyprawić się jedynie przeciw Gotom, por. Thompson, Hunowie, s. 112.

${ }^{67}$ Pryskos (Fragmenta 20, ed. Blockley, s. 306-307) wspomina także o pewnej roli Gejzeryka, któremu Attyla miał w ten sposób wyświadczyć przysługę. Mało jest jednak prawdopodobne, by faktycznie powstał taki sojusz. Wandalsko-huńska „oś zła” jest albo wymysłem rzymskich autorów, albo dotyczy pewnych dyplomatycznych przygotowań, jakie czynił Attyla wobec Zachodu, w tym także wobec Wandalów Gejzeryka, jednak nie szły za tym żadne konkretne porozumienia, por. F.M. Clover, Gaiseric and Attila, „Historia” 22 (1973) 115. Otto Maenchen-Helfen (The World of Huns, s. 107) stwierdza zresztą, że Attyla rozważał atak na Zachód już w latach 40.

${ }^{68}$ Por. Rouche, Attyla i Hunowie, s. 123-124.

${ }^{69}$ Początkowo spodziewano się ataku na Italię, o czym w swych listach informuje papież Leon, por. Maenchen-Helfen, The World of Huns, s. 129. 
usprawiedliwiają nieobecność biskupów zachodnich na soborze w Chalcedonie, zdają się sugerować, iż kierunek uderzenia Attyli był znany. Nawet jeśli Marcjan skoncentrował swe siły w Tracji, oczekując zmasowanego ataku, nic, poza jego własną wolą, nie broniło go od wyruszenia na pomoc Cesarstwu Zachodniemu, gdy już przekonał się, że ma do czynienia jedynie z podjazdami wroga. Kolejną kwestią sporną jest chronologia wydarzeń. Informacje źródłowe świadczące o obecności Marcjana w Tracji oraz o zagrożeniu prowincji Moesia Prima i Dacia Ripensis ${ }^{70}$ pochodzą z sierpnia, czyli z okresu po bitwie na Polach Katalaunijskich. Oczywiście nie można wykluczyć, że ziemie te były zagrożone już wcześniej, ale równie prawdopodobne wydaje się, że zostały one zaatakowane przez powracających z Galii Hunów ${ }^{71}$. Trzeba bowiem pamiętać, iż porażka Attyli nie była całkowita i nadal posiadał on zdolne do walki oddziały. Jest też możliwe, że czesść z nich na własną rękę ruszyła łupić ziemie Cesarstwa Wschodniego, sfrustrowana porażką i brakiem łupów, co również wyjaśniałoby brak odnotowania tego wydarzenia w pozostałych źródłach, jako niezwiązanego z wielką polityką Attyli, a przeto mało znaczącego ${ }^{72}$.

Bez względu na przebieg tych wydarzeń nie ma żadnego powodu, by twierdzić, że Marcjan w ogóle myślał o wsparciu Cesarstwa Zachodniego w 451 roku. Wyraźnie miał jedynie na uwadze bezpieczeństwo swej północnej granicy i wyłącznie tam skoncentrował działania swych wojsk. Na szczęście dla Rzymu patrycjusz Aecjusz stanął na wysokości zadania i odparł, choć nie bez trudności, najazd Hunów. Rok później sytuacja była jednak drastycznie inna. Choć siły Attyli prawdopodobnie doznały poważnego uszczerbku podczas poprzedniej kampanii ${ }^{73}$, sam rzymski wódz był w jeszcze trudniejszej sytuacji. Tym razem nie mógł liczyć na siły Gotów i Alanów, pochłoniętych walkami wewnętrznymi. Prosper oskarża Aecjusza, że dał się zaskoczyć i nie zrobił nic, by powstrzymać armię wroga przed wkroczeniem do Italii przez alpejskie przełęcze ${ }^{74}$. Można się jednak zastanawiać, czy posiadał ku temu środki, biorąc pod uwagę dotkliwą nieobecność foederati, którzy odegrali kluczową rolę w zeszłorocznej kampanii. Hunowie, nie niepokojeni, rozlali się po Nizinie Padańskiej zdobywając i łupiąc między innymi Akwileję, Mediolan i Pawię. Ponoć Attyla zamierzał kontynuować marsz na sam Rzym, jednak, według przekazu Jordanesa $^{75}$, został odwiedziony od tego pomysłu przez swoich pobratymców, zaś do wycofania się przekonało go poselstwo papieża Leona, co poświadcza również

${ }^{70}$ Por. tamże, s. 131.

${ }^{71}$ Por. Pawlak, Aecjusz i barbarzyńcy, s. 264; Hohlfelder, Marcian's Gamble, s. 61.

${ }^{72}$ Chyba że weźmiemy pod uwagę przekaz Jana Malalasa (Chronographia XIV 10, CFHB Series Berolinensis 35, s. 279), który wspomina o walkach nad Dunajem, lecz wiąże je z wydarzeniami w Galii i z Aecjuszem. Możliwe, że niezorientowany w realiach zachodnich kronikarz połączył dwa różne, lecz nieodległe od siebie chronologicznie wydarzenia.

${ }^{73}$ Por. Maenchen-Helfen, The World of Huns, s. 132.

${ }^{74}$ Por. Prosper Aquitanus, Epitoma Chronicon 1367, MGH Auctores Antiquissimi IX 482.

${ }^{75}$ Por. Iordanes, Getica 223, ed. Th. Mommsen, MGH Auctores Antiquissimi V/1, Berolini 
Prosper $^{76}$. Nie jest niczym dziwnym, że sam sekretarz papieża, $\mathrm{w}$ dodatku niechętnie odnoszący się do Aecjusza, przyjął taką interpretację. Możemy jednak być pewni, że autorytet biskupa Rzymu nie robił wrażenia na barbarzyńskim władcy $^{77}$. Powody jego wycofania się musiały być inne. Prawdopodobnie zdobyto tyle łupów, że dotychczas mobilne hordy barbarzyńców poruszały się niezwykle wolno ${ }^{78}$. Z pewnością utrudniałoby to marsz na Rzym, co wyjaśnia zawartą u Jordanesa informację, dlaczego pobratymcy Attyli odwodzili go od uderzenia na Wieczne Miasto - zapewne usatysfakcjonowani pozyskanym bogactwem, chcieli wracać do swych domów. Kolejną, znacznie poważniejszą kwestią był wybuch zarazy, o czym dowiadujemy się z przekazu Hydacjusza ${ }^{79}$. Malaryczne bagna Niziny Padańskiej nie sprzyjały utrzymaniu zdrowia wśród tak dużych skupisk ludzkich, szczególnie pewnie mniej dbałych o higienę hord barbarzyńców, o czym przekonał się także Alaryk 50 lat wcześniej ${ }^{80}$. Jednak swój udział w porażce Attyli w Italii w 452 r. miał także Marcjan. Cesarz wysłał bowiem Aecjuszowi posiłki, których ten użył do pokonania ${ }^{81}$ osłabionych zarazą barbarzyńców. Sam natomiast przeprawił swe wojska za Dunaj, aby uderzyły bezpośrednio na siedziby barbarzyńców ${ }^{82}$. W tym ciągu wydarzeń zastanawiające są zwłaszcza dwie rzeczy. Po pierwsze, co tym razem skłoniło cesarza

1882, 115, tłum. E. Zwolski: Kasjodor i Jordanes. Historia gocka czyli scytyjska Europa, Rozprawy Wydziału Historyczno-Filologicznego 49, Lublin 1984, 129.

${ }^{76}$ Por. Prosper Aquitanus, Epitoma Chronicon 1367, MGH Auctores Antiquissimi IX 482.

${ }^{77}$ Prawdziwym celem poselstwa były pewnie negocjacje o uwolnienie jeńców, por. MaenchenHelfen, The World of Huns, s. 140-141; Rouche, Attyla i Hunowie, s. 141.

${ }^{78}$ Por. Maenchen-Helfen, The World of Huns, s. 139.

${ }^{79}$ Por. Hydatius, Chronica Subdita 146, ed. Burgess, s. 102.

${ }^{80}$ Por. Claudius Claudianus, De sexto consulatu Honorii Augustii 300-304, ed. with an English translation by M. Platnauer, w: Claudian, vol. 2, LCL 136, London 1922, 96. Podobny los spotka1 Franków w 540 r., gdy stracili 1/3 swej armii (zob. Procopius Caesariensis, De bellis libri VI 25, 17-18, rec. J. Havry, addenda et corrigenda adiecit G. Wirth, w: Procopii Caesariensis Opera omnia, vol. 2, Lipsiae 1963, 263, 27 - 264, 6, thum. D. Brodka: Historia wojen, t. 2: Wojny z Gotami, Źródła Historyczne, Kraków 2015, 182) oraz ponownie w 553, gdy zaraza wybiła niemal całą armię (zob. Agathias Myrinaeus, Historiarum libri quinque II 3, rec. R. Keydell, CFHB Series Berolinensis 2, Berolini 1967, 43-44), straty Hunów musiały być zatem bardzo dotkliwe. Zob. Maenchen-Helfen, The World of Huns, s. 139-140.

${ }^{81}$ Hydacjusz (Chronica Subdita 146, ed. Burgess, s. 102) używa dosłownie słowa „wyciąć” (caedo) co wskazuje na to, że Attyla musiał ponieść sromotną porażkę. Jednak biorąc pod uwagę raczej skromne siły Aecjusza, najpewniej owa „bitwa” była niewielka, choć być może istotną w całej kampanii, potyczką z jakąś częścią sił huńskich.

${ }^{82}$ Por. Bóna, Das Hunnenreich, s. 99. Podobnie stwierdza Thompson (Hunowie, s. 125), jednak błędnie przyjmuje, że był tylko jeden kontyngent wojsk wschodnich, kierujący się przeciw barbarzyńcom, którym dowodził jakiś bliżej nieznany Aecjusz. Możemy mieć pewność, że chodzi o sławnego zachodniego patrycjusza Aecjusza, gdyż Hydacjusz (Chronica Subdita 146, ed. Burgess, s. 102) wyraźnie rozróżnia posiłki (auxillium) dla niego od sił, których Marcjan użył do inwazji na siedziby Hunów (exercitum). 
Marcjana do zaangażowania się w sprawy Cesarstwa Zachodniego, a po wtóre, dlaczego żadne źródło poza Hydacjuszem nie wspomina o tym epizodzie ${ }^{83}$.

Zwłaszcza drugi problem wydaje się szczególnie interesujący. Marcjan był konsekwentnie uważany przez dziejopisów antycznych za bardzo dobrego cesarza. Nie było zatem żadnego powodu, aby umniejszać jego zasługi, a wręcz przeciwnie. Zrozumiałe, że Prosper wolał przypisywać wycofanie się Attyli cudownemu wstawiennictwu papieża, ale jest niezwykle dziwne, że wschodni historycy nie pokusili się nawet o najmniejszą wzmiankę na temat tych wydarzeń. Zarówno Prokopiusz, Ewagriusz, jak i Teofanes korzystali głównie z dzieła Pryskosa, opisując wydarzenia z czasów panowania Marcjana. Wniosek jaki się zatem nasuwa, jest taki, że sam Pryskos musiał w swej Historii owe wydarzenia po prostu pominąć. Mało prawdopodobne jest, by historyk, skądinąd doskonale zorientowany w polityce zagranicznej i dyplomacji, o działaniach wojskowych cesarza nie wiedział. Nie ma również powodu by twierdzić, że chciał obniżyć zasługi Marcjana, którego bardzo cenił. W takim wypadku fakt, iż Pryskos przemilcza informacje o interwencji, wydaje się wskazywać, iż musiała ona zawierać dodatkowy aspekt, który skłonił historyka do przemilczenia sprawy.

Można się zastanawiać, co mogło wywołać taką reakcję. Jedyną rzeczywiście kontrowersyjną kwestią w rządach Marcjana były jego słabe prawa do tronu. Być może pomoc militarna była ceną za pozbycie się wszelkich pretensji przez Walentyniana III do rządów nad całością Imperium ${ }^{84}$. Pryskos wspominając o tym fakcie eksponowałby, wbrew oficjalnej propagandzie cesarskiej, brak legitymizacji rządów Marcjana. Biorąc pod uwagę, że był za jego panowania urzędnikiem państwowym, podjęcie przez niego decyzji o przemilczaniu tych wydarzeń byłoby zrozumiałe. Takie wyjaśnienie tłumaczy także postawę Aecjusza. Wódz, bez względu na swe militarne talenty, nie miał skąd zebrać wystarczających sił do walki z Hunami. Jak zauważa Otto Maenchen-Helfen, gdy Aecjusz dowiedział się o planach Hunów, zwrócił się do cesarza wschodniorzymskiego, jako jedynej osoby zdolnej udzielić mu wsparcia militarnego ${ }^{85}$. W zamian wymusił na Walentynianie III uznanie władzy Marcjana ${ }^{86}$. Bezczynność wodza w początkowej fazie konfliktu była spowodowana nie tyle nieudolnością czy zaskoczeniem, co oczekiwaniem na posiłki. Aecjusz prawdopodobnie liczył na to, że mury Akwilei powstrzymają najeźdźców, aż zdąży

${ }^{83}$ Jak twierdzi Richard Burgess (A New Reading for Hydatius ,, Chronicle” 177 and the Defeat of the Huns in Italy, „Phoenix” 42:1988, 363) Hydacjusza w błąd wprowadzili jego informatorzy, kupcy ze Wschodu. Z uwagi na milczenie innych źródeł stwierdza, że nie ma dowodów na to, że Marcjan w jakikolwiek sposób angażował się przeciw Hunom w 452 roku. Nie uważam jednak tego argumentu za przekonywujący, gdyż źródła do panowania Marcjana i tak są nieliczne, natomiast brak informacji na ten temat można tłumaczyć na inne sposoby, co czynię w dalszej części artykułu.

${ }^{84}$ Por. Twardowska, Rzymski Wschód, s. 99; Pawlak, Aecjusz i barbarzyńcy, s. 268.

${ }^{85}$ Por. Maenchen-Helfen, The World of Huns, s. 138.

${ }^{86}$ Kolejną przesłanką świadczącą o jakichś związkach między Aecjuszem a Marcjanem, które naruszały interesy Walentyniana, znajdujemy u Pryskosa (Fragmenta 30, ed. Blockley, s. 326-329). Młody władca miał oskarżyć wodza o to, że pozbawił go władzy na Wschodzie na rzecz Marcjana. 
zebrać siły, jednak upadek twierdzy umożliwił Hunom wtargnięcie do Italii. Być może to wpłynęło na decyzję Marcjana o ataku za Dunaj, by odciążyć sojusznika. W ten sposób, angażując minimalne środki (wszak korpus wysłany Aecjuszowi raczej nie był zbyt liczny, chociażby z uwagi na kłopoty związane $\mathrm{z}$ transportem armii drogą morską, zaś splądrowanie niebronionych wiosek barbarzyńców z pewnością nie wymagało wielkich sił i nakładów) Marcjan był w stanie zarówno zalegalizować swoją władzę oraz zadać poważny cios Hunom. Po raz kolejny władca unikał ryzyka i wykazywał się ostrożnościa, jednak poprzez swe działania dyplomatyczne i militarne w 452 r. udowodnił, że potrafi wykorzystać nadarzającą się okazję.

Zachowawczość polityki Marcjana, połączona z pewną elastycznością, opłaciła się Bizancjum. Z jednej strony Attyla poniósł dwie porażki, z drugiej zaś, to Cesarstwo Zachodnie musiało zapłacić cenę za jego pokonanie. Dla władcy Hunów, którego potęga opierała się na autorytecie zwycięzcy, zapewniającego chwałę i łupy, sytuacja jaka spotkała go w latach 451-452 musiała być bardzo trudna ${ }^{87}$. Przypuszczalnie pierwsze pęknięcia pojawiły się tuż po kampanii w Galii, bowiem krótki odstęp czasu między nią a inwazją na Italię (bez względu na trudną sytuację militarną związaną z wcześniejszą porażką) wydaje się wskazywać na presję ze strony wodzów podległych Attyli ${ }^{88}$. Ponadto decyzja Marcjana o niepłaceniu Hunom trybutu oraz jego twarda postawa wobec gróźb Attyli, także musiały nadszarpnąć autorytet tego ostatniego. Niestety, ze względu na brak informacji o sytuacji wewnętrznej w imperium Hunów, możemy sobie tylko wyobrażać jak napięte musiały być relacje między władcą a jego poddanymi, szczególnie niezwiązanymi etnicznie plemionami germańskimi ${ }^{89}$. Zastanawiające jest, że właśnie w takim momencie Marcjan zdecydował się najechać siedziby barbarzyńców. Być może znał słabość swego rywala, miał bowiem dostęp do informacji o funkcjonowaniu państwa Hunów ${ }^{90}$, czego świadectwem jest chociażby wspomniany wcześniej raport Pryskosa z Panion. Można przypuszczać, że prowadził świadomie działania mające na celu zburzenie autorytetu Attyli i podkopanie fundamentów, na których opierało się jego imperium ${ }^{91}$.

Trudno jednak jednoznacznie ocenić, jaka była ich skuteczność, bowiem w 453 r. Attyla zmarł. Wydarzyło się to tuż po ślubie z Ildico, prawdopodobnie germańską księżniczką. Władca na weselu wypił dużo wina i podczas nocy poślubnej dostał krwotoku wewnętrznego, w wyniku czego miał nastąpić zgon ${ }^{92}$.

${ }^{87}$ Por. Thompson, Hunowie, s. 125.

${ }^{88}$ Por. Maenchen-Helfen, The World of Huns, s. 132.

${ }^{89}$ Por. tamże, s. 143; Heather, Upadek Cesarstwa Rzymskiego, s. 424-425.

${ }^{90}$ Por. Tyszkiewicz, Hunowie w Europie, s. 58.

${ }^{91}$ Które prawdopodobniej były stosunkowo wątłe, por. P. Heather, Imperia i barbarzyńcy, thum. J. Szczepański, Historia - Rebis, Poznań 2010, 258-259; Pawlak, Aecjusz i barbarzyńcy, s. 269-270.

${ }^{92}$ Por. Iordanes, Getica, 254, MGH Auctores Antiquissimi V/1 123-124, thum. Zwolski, s. 134. Owa relacja jest sprzeczna jednak z wizerunkiem Attyli, który przedstawia nam Pryskos. Według dyplomaty Attyla odznaczał się umiarkowaniem i skromnością, co przede wszystkim przejawiało 
Istniejąjednak pewne wątpliwości, czy była to śmierć z powodów naturalnych. Wydaje się, że Pryskos sugerował jeszcze inną alternatywę, a mianowicie, że Attyla zginął od ciosu nożem, który zadała mu jego nowo zaślubiona żona ${ }^{93}$. Władca prawdopodobnie pojął Ildico za żonę, by umocnić sojusze łączące go z Germanami, niewątpliwie nadwątlone po porażkach z lat 451 i 452. Niewykluczone, że jakieś większe niepokoje wśród poddanych Attyli wybuchły tuż po powrocie z wyprawy italskiej, które ten krwawo zdławił. Być może wśród Germanów zawiązał się spisek, w którym Ildico wzięła udział, lub samodzielnie zdecydowała zemścić się za śmierć swych pobratymców ${ }^{94}$.

Bez względu na kulisy śmierci Attyli w 453 r., dzięki pragmatycznej polityce Marcjana wobec Hunów, ich imperium zaczęło się rozsypywać. Smierć króla tylko przypieczętowała rozkład, ale władca, nawet gdyby żył, musiałby zmagać się z problemami wewnętrznymi. Dowodem na to są kłótnie o władzę między synami Attyli ${ }^{95}$, mimo że ten jasno wyznaczył na swego następcę najstarszego z nich, Ellaka ${ }^{96}$. To zaś oznacza, że prestiż władcy znacząco podupadł, skoro nie był w stanie zapewnić spokojnej sukcesji. W tym samym czasie zbuntowali się także Gepidowie, którzy pokonując Hunów nad rzeką Nedao i zabijając Ellaka, zajęli ich siedziby, a następnie wysłali poselstwo do Marcjana z prośbą o pokój i trybut. To pokazuje, jak zmieniła się sytuacja w regionie przez ostatnie lata. Cesarz rzymski ponownie stał się osoba, do której ludy barbarzyńskie ciagnęły pod opiekę. Prośba o pokój może świadczyć o tym, że najazd z 452 odcisną się mocno w świadomości barbarzyńców, zaś trybut był zapewne związany z zawarciem foedus, a zatem Gepidowie faktycznie oddawali się w zależność od cesarza. Marcjan bardzo chętnie przyjął tę propozycję, zyskiwał bowiem spokój nad Dunajem oraz tworzył z Dacji strefe

się w jego prostym odzieniu oraz w używaniu drewnianej zastawy zamiast wykonanej z drogich metali. Niektórzy autorzy twierdza, że to pozostałość zwyczajów z dawnych nomadycznych czasów (zob. Tyszkiewicz, Hunowie w Europie, s. 69-70; Rouche, Attyla i Hunowie, s. 169), a więc nie świadczą o jakichś szczególnych cechach władcy. Ciekawe jest również spostrzeżenie Magdaleny Mączyńskiej (Światto z popiołu. Wędrówki ludów w Europie w IV i V wieku, Warszawa 2013, 121) wysnute na podstawie znalezisk z Szeged-Nagyszéksés, która zauważa, że Hunowie używali drewnianych kielichów obitych złotymi okuciami, wysoce ozdobnych i drogocennych. A zatem Pryskos mógł przedstawić tylko pół prawdy. Zapewne historykowi zależało na zestawieniu prostolinijnego barbarzyńskiego władcy z chciwym eunuchem Chryzafiuszem i pozwalało mu na moralizatorskie konkluzje. Nie należy więc twierdzić, że Attyla był jakoś szczególnie wstrzemięźliwy, jeśli chodzi o obnoszenie się z bogactwem, ucztowanie czy relacje z kobietami.

${ }^{93}$ Taką interpretację przyjmuje Marcellin Komes (Chronicon a. 454, ed. Croke, s. 21-22) oraz Jan Malalas (Chronographia XIV 10, CFSB Series Berolinensis 35, s. 279), który zresztą wskazuje Pryskosa jako źródło informacji.

${ }^{94}$ Edward A. Thompson (Hunowie, s. 128) podaje przykład jednej z sag skandynawskich, w której pojawia się motyw Attyli ginącego z ręki swej żony, która miała pomścić w ten sposób swych braci. Sam historyk nie wierzy jednak w to, by Attyla zginął zamordowany.

${ }^{95}$ Por. Iordanes, Getica 259, MGH Auctores Antiquissimi V/1 125, thum. Zwolski, s. 136.

${ }^{96}$ Por. Priscus, Fragmenta 13, ed. Blockley, s. 284-289; Iordanes, Getica 262, MGH Auctores Antiquissimi V/1 125, thum. Zwolski, s. 136. 
buforową za północną granica, zbudowaną z tarcz gepidzkich wojowników. Poza wspomnianymi Gepidami także inne plemiona, niegdyś zależne od Attyli, szukały porozumień z cesarzem. Marcjan wpuścił ich na ziemie wyludnione wcześniej przez najazdy Hunów. I tak Ostrogoci zostali osadzeni w Panonii, Sarmaci i część Hunów w Scytii i Dacji Ripensis, Skirowie i Alanowie w Scytii i Mezji Dolnej, Rugiowie zaś w Tracji ${ }^{97}$. Marcjan, dzięki swej pragmatycznej polityce zewnętrznej, w ciągu 3 lat praktycznie zneutralizował zagrożenie ze strony Hunów, którzy jeszcze za czasów jego poprzednika dyktowali warunki Konstantynopolowi i stanowili ciagłe niebezpieczeństwo. W pełni zabezpieczył północną granicę, a dzięki wpuszczeniu barbarzyńców na wyludnione wcześniej przez najazdy Hunów ziemie, częściowo naprawił zniszczenia spowodowane tymi najazdami ${ }^{98}$.

4. Polityka zachodnia Marcjana w latach 453-457. Jednak nawet po zlikwidowaniu zagrożenia huńskiego Marcjan nie zmienił swej wstrzemięźliwej polityki zewnętrznej w stosunku do Zachodu i nie zareagowal, gdy prowadzona była tam dramatyczna walka o władzę. W 453 r. Walentynian III, ponoć własnoręcznie, zabił Aecjusza ${ }^{99}$. Władca chciał pozbyć się potężnego i faktycznie rządzącego państwem wodza oraz odzyskać kontrolę, zwłaszcza nad armią. W następnym okresie cesarz podejmował szereg starań by podporządkować sobie siły zbrojne Zachodu ${ }^{100}$, lecz dziedzictwo Aecjusza było zbyt silne. Sentyment żołnierzy do wodza wykorzystał Petroniusz Maksymus. Choć sam namawiał wcześniej cesarza do zgładzenia Aecjusza, licząc na cesarską łaskę i stanowiska, to nie otrzymawszy jej, sam zawiązał spisek przeciw Walentynianowi ${ }^{101}$. Przekonał dwóch żołnierzy z gwardii cesarskiej, Optylę i Thraustylę, że śmierć wodza należy pomścić, a ludzie, którzy tego dokonają zostaną sowicie wynagrodzeni. Gwardziści zrozumieli aluzję i po

${ }^{97}$ Por. Iordanes, Getica 264-266, MGH Auctores Antiquissimi V/1 126-127, thum. Zwolski, s. 136-137; Twardowska, Rzymski Wschód, s. 100; H. Wolfram, Historia Gotów, thum. A. Darda-Staab i inni, Warszawa - Gdańsk 2003, 299-301. Warto zwrócić uwagę na kwestię Panonii, bowiem można mieć wątpliwości, czy Marcjan miał prawo swobodnie rozporządzać tą prowincją gdyż formalnie należała do Cesarstwa Zachodniego. Więcej o tym problemie i otaczającej go dyskusji naukowej zob. H. Gračanin - J. Škrgulja, The Ostrogoths in the Late Antique South Pannonia, „Acta Archeologica Carpathica” 49 (2014) 169-170. Ponadto nie wiadomo czy Goci faktycznie przybyli na te ziemie, czy też zamieszkiwali je wcześniej, gdy znajdowały się pod kontrolą Hunów. Por. P. Heather, Goths and Romans 332-489, Oxford 1991, 242.

${ }^{98}$ Ważną rolę w tym przedsięwzięciu pełnił przyszły cesarz zachodniorzymski, Prokopiusz Antemiusz, który został wysłany nad Dunaj, najpewniej z misją dyplomatyczną do nowo pozyskanych sojuszników. Por. Sidonius Apollinaris, Carmina II 199, w: tenże, Poems and Letters (Books I-II), ed. with an English translation by W.B. Anderson, LCL 296, London 1956, 24-25; Heather, Goths and Romans, s. 44.

${ }^{99}$ Por. Priscus, Fragmenta 30, ed. Blockley, s. 328-329; P. Heather, The Huns and the End of the Roman Empire in Western Europe, „English Historical Review” 110 (1995) 29.

${ }^{100}$ Por. S. Oost, Aetius and Majorian, CPh 59 (1964) 24-25.

${ }^{101}$ Por. Priscus, Fragmenta 30, ed. Blockley, s. 328-333. 
kilku dniach zabili Walentyniana III, zabrali jego diadem i zawieźli Petroniuszowi Maksymusowi.

Przez pewien czas Rzym ogarnięty był chaosem i walką między różnymi stronnictwami, gdyż Petroniusz Maksymus nie cieszył się powszechnym poparciem. Niektórzy preferowali niejakiego Maksymina, zaś Eudoksja, wdowa po Walentynianie, miała rozważać kandydaturę Majoriana, młodego dowódcy związanego z Aecjuszem ${ }^{102}$. Ostatecznie Petroniusz Maksymus skonsolidował swą władzę, głównie poprzez rozdawnictwo cesarskiego złota. Niedługo jednak cieszył się swymi rządami, gdyż król Wandalów, Gejzeryk, gdy tylko dowiedział się o śmierci Aecjusza i Walentyniana, z którymi łączył go układ pokojowy, stwierdził, że przestaje on obowiązywać. Prawdopodobnie był to tylko pretekst, a prawdziwym powodem ataku była słabość Cesarstwa. W 455 r. flota Wandalów wyruszyła na Rzym. Barbarzyńcy splądrowali Wieczne Miasto i porwali Eudoksję z jej obiema córkami, Eudocją i Placydia, zaś Petroniusz Maksymus został zabity przez mieszkańców, a jego ciało rozdarto na strzępy ${ }^{103}$. Gejzeryk zajął także Sycylię, Korsykę, Sardynię i inne wyspy na Morzu Sródziemnym ${ }^{104}$. Cesarstwo Zachodnie pogrążyło się w kompletnym chaosie.

Mimo to Marcjan praktycznie nie zareagował ${ }^{105}$. Wysłał co prawda do Gejzeryka poselstwo z żądaniem zaprzestania najazdów i zwrotu kobiet z rodziny cesarskiej, ale król zignorował wysłanników cesarza. Wobec początkowego fiaska, Marcjan wysłał drugie poselstwo z Bleda, ariańskim biskupem na czele. Jest to bardzo ciekawe posunięcie, wskazujące $z$ jednej strony na pragmatyzm cesarza, bowiem zdecydował się powierzyć tak ważną sprawę w ręce heretyka, a z drugiej, wyraźnie sugerujące chęć porozumienia. Choć Bleda później przyjął bardziej drapieżną retorykę, sam fakt wysłania go świadczy o dobrej woli cesarza wobec Gejzeryka. Żądania Marcjana również nie były wygórowane. Rozwiązanie, które proponował, nie była nawet powrotem do status quo, Gejzeryk wszakże zatrzymywałby wszystkie pozostałe łupy. Jednak władca Wandalów był wyjątkowo zręcznym politykiem i chyba zdawał sobie sprawę, że w danej chwili jest panem sytuacji, zaś groźby Marcjana nie niosą za sobą żadnego realnego zagrożenia. Miał widocznie rację, gdyż nie mamy żadnych dowodów na to, by cesarz w jakikolwiek sposób wsparł Zachód $\mathrm{w}$ konfrontacji $\mathrm{z}$ Wandalami, nie mówiąc o samodzielnych działaniach ${ }^{106}$. Prawdopodobnie politycznym wymogiem było, aby Marcjan wyraził oburzenie ze względu na działania Gejzeryka. Zapewne jednak nie zależało

${ }^{102}$ Możliwe, że Majorian był szykowany na męża dla Placydii, a zatem na potencjalnego następcę Walentyniana III, por. Oost, Aetius and Majorian, s. 27-28.

103 Por. Priscus, Fragmenta 30, ed. Blockley, s. 330-333.

104 Por. Victor Vitensis, Historia persecutionis vandalicae I 4, PL 58, 186A - 187A, thum. J. Czuj: Wiktor z Wity, Dzieje prześladowania Kościoła w Afryce przez Wandalów, POK 14, Poznań 1930 [reprint: Poznań 2005], 38-39.

${ }^{105}$ Marek Wilczyński (Zagraniczna i wewnętrzna polityka, s. 65) wyjaśnia to wpływem Aspara na dworze w Konstantynopolu.

${ }^{106}$ Choć nie można wykluczyć, że planował takie przedsięwzięcie, zob. nota. 113. 
mu specjalnie, żeby podejmować jakieś szeroko zakrojone działania na rzecz kobiet z dynastii teodozjańskiej, z której przecież sam nie pochodził.

Ciekawego, pośredniego dowodu na niechęć Marcjana do mieszania się w wojnę z Wandalami dostarcza Prokopiusz, najpewniej opierając się na dziele Pryskosa. Marcjan bowiem, gdy był w niewoli u Wandalów, miał obiecać Gejzerykowi, że nigdy nie wyprawi się przeciw jego ludowi ${ }^{107}$. Oczywiście sam fakt wystąpienia takiego wydarzenia, jako powiązany z wróżbą zwiastującą Marcjanowi tron, jest mocno dyskusyjny. Dużo bardziej prawdopodobnym wydaje się, że owa historia jest echem oficjalnej propagandy cesarskiej. Zdobycie Rzymu w 455 r. było wstrząsem dla mieszkańców całego Imperium i na Marcjanie ciążyła spora presja, aby pomścić krzywdę wyrządzoną Wiecznemu Miastu. Dlatego puszczono w obieg tę wiadomość, która miała niejako usprawiedliwić bezczynność cesarza, a w rzeczywistości była ona grosso modo podyktowana względami pragmatycznymi ${ }^{108}$.

Po śmierci Petroniusza Maksymusa tron cesarski pozostawał pusty. Nie wiemy nic o tym, aby Marcjan miał jakiekolwiek pretensje do wyznaczenia następcy. Gdy po władzę sięgną magister militum per Gallias Awitus, przy wsparciu Teodoryka II, króla Gotów, Marcjan nie uznał jego rządów ${ }^{109}$. Trudno jednoznacznie stwierdzić dlaczego, zwłaszcza że sam Awitus zabiegał o wsparcie ${ }^{110}$. Prawdopodobnie sceptycznie odnosił się do władcy, który zdobył tron przy poparciu prowincjonalnej arystokracji i barbarzyńskiego króla oraz był niechętnie przyjmowany w samej stolicy. Być może przypuszczał, że Awitus nie zdoła ogarnąć chaosu, który opanował Zachód. Możliwe też, że zwlekał, oczekując na rozwój sytuacji, zwłaszcza że nadal prowadził pertraktacje z Wandalami ${ }^{111}$. Ralph Mathisen twierdzi, że Marcjan planował zaangażować się na Zachodzie dopiero, gdy uspokoi się sytuacja na Bałkanach i w Lazyce ${ }^{112}$. Cesarz miał przygotowywać się do wyprawy przeciw Wandalom ${ }^{113}$, do czego

${ }^{107}$ Por. Procopius Caesariensis, De bellis III 4, 10-11, rec. Havry - Wirth, vol. 1, s. 325, 26 - 326, 7, tłum. Brodka, t. 1, s. 216. Historyk stwierdza też, że brak zainteresowania sprawami w Afryce był jedyną wadą tego cesarza.

${ }^{108}$ Por. Thompson, The Foreign Policies, s. 68-69.

109 Por. R.W. Mathisen, Avitus, Italy and the East in A.D. 455-456, „Byzantion” 51 (1981) 235-237.

${ }^{110}$ Por. Hydatius, Chronica Subdita 159, ed. Burgess, s. 104.

${ }^{111}$ Por. Mathisen, Avitus, Italy and the East in A.D. 455-456, s. 242.

112 Por. tamże, s. 243. Polityka wschodnia Marcjana pozostaje poza zakresem tematycznym tego artykułu, należy jednak wspomnieć, że cesarz zaangażował się w celu wciagnięcia Lazyki w swoją strefę wpływów. Zob. Priscus, Fragmenta 33, ed. Blockley, s. 336-339. Nie należy jednak sądzić, że było to przedsięwzięcie pochłaniające większość uwagi i środków władcy.

${ }^{113}$ Por. Theodorus Lector, HE I 7, PG 86, 169 A. Ta wzmianka i groźba posła Bledy (Priscus, Fragmenta 31, ed. Blockley, s. 334-335) są jednak jedynymi świadectwami sugerującymi, że Marcjan szykował się do wojny. Choć nie jestem przekonany, czy Marcjan rzeczywiście chciał w końcowym etapie swego panowania wyprawić się przeciw Wandalom, to z pewnością, nauczony doświadczeniem klęsk Teodozjusza II, poruszał się z wielką ostrożnością i starał się zabezpieczyć na każdą ewentualność. 
potrzebował wsparcia Awitusa. Ten odnosił już w walkach z barbarzyńcami zagrażającymi Rzymowi pewne sukcesy, takie jak zwycięstwo nad Wandalami na Sycylii pod Agrygentem ${ }^{114}$ czy podporządkowanie swej władzy plemion gockich i burgundzkich ${ }^{115}$, nie zdołał jednak skonsolidować swej władzy w samej Italii. Gdy Marcjan był już gotów uznać władzę Awitusa, na Zachodzie wybuchł kryzys ${ }^{116}$. Ze względu na rajdy wandalskich korsarzy mieszkańcom Rzymu dokuczał głód, który potęgowany był przez obecność gockich oddziałów w mieście. Przy wzrastającym niezadowoleniu, Awitus zdecydował się odesłać swych sprzymierzeńców, jednak paradoksalnie pogorszyło to tylko sytuację. Spiskowcy, Majorian i Rycymer, zostali tylko zachęceni do działania. Pierwszym ich ruchem było zamordowanie jednego z popleczników Awitusa, patrycjusza Remistiusza. Cesarz zorientował się w swym położeniu i wysłał prośbę o pomoc do Teodoryka II, przebywającego w Hiszpanii, który prowadził tam kampanię przeciw Swebom. Sam zebrał wierne mu wojska i ruszył na Północ, by połączyć siły ze sprzymierzeńcem, jednak Majorian i Rycymer zagrodzili mu drogę w pobliżu Placencji. Doszło tam do bitwy, która przyniosła Awitusowi klęskę. Został zmuszony do przyjęcia sakry biskupiej, a wkrótce po tym zmarł. Majorian z Rycymerem stali się panami sytuacji.

Marcjan biernie obserwował te wydarzenia. Jeśli rzeczywiście planował wejść w porozumienie z Awitusem, to bynajmniej nie zamierzał angażować jakichkolwiek środków, by pomagać mu w rozwiązywaniu problemów wewnętrznych. Przejęcie władzy przez spiskowców również nie spotkało się z jego reakcją. Od października aż do śmierci samego Marcjana w styczniu 457 r., Konstantynopol nie zrobił nic, by zakończyć anarchię na Zachodzie ${ }^{117}$. Inną ciekawą kwestią są relacje między Marcjanem a Marcellinem z Dalmacji. Niewiele wiemy o karierze tego drugiego. Prawdopodobnie pochodził z lokalnej arystokracji ${ }^{118}$. Być może był tamtejszym dowódcą wojskowym, jednak biorąc pod uwagę fakt, że opierał się głównie na najemnikach ${ }^{119}$, zaś Cesarstwo

${ }^{114}$ Por. Sidonius Apollinaris, Carmina II 366-367, LCL 296, 38-40. Można mieć wątpliwości, czy to zwycięstwo było rzeczywiście znaczące, zwłaszcza że informację o nim posiadamy z panegiryku, czyli dzieła propagandowego. Wszakże Wandalowie bynajmniej nie zaprzestali prowadzić szeroko zakrojonej kampanii przeciw Cesarstwu.

115 Por. D. Zołoteńki, Galia u schyłku panowania rzymskiego: administracja cywilnai wojskowa oraz jej reprezentanci w latach 455-486, Notos. Scripta Antiqua et Byzantina 6, Kraków 2011, 127-128.

${ }^{116}$ Por. Mathisen, Avitus, Italy and the East in A.D. 455-456, s. 244.

${ }^{117}$ Mianowanie Majoriana magistrem militum, a Rycymera patrycjuszem było już raczej decyzją Leona, gdyż Marcjan z pewnością zmarł w styczniu, najpewniej 27 dnia tego miesiąca, por. B. Croke, The Date and Circumstances of Marcian's Decease, A.D. 457, „Byzantion” 48 (1978) 9.

${ }^{118}$ Por. P. MacGeorge, Late Roman Warlords, Oxford Classical Monographs, Oxford - New York 2002, 42. To wyjaśniałoby jego późniejszą niezależność i wpisywało się w typowy dla terenów Cesarstwa Zachodniorzymskiego mechanizm decentralizacji władzy w związku z rosnącymi zagrożeniami.

${ }^{119} \mathrm{Na}$,Scytach”, jak wspomina Pryskos (Fragmenta 38, ed. Blockley, s. 340-341), co wskazuje najprawdopodobniej na Hunów lub Ostrogotów, por. MacGeorge, Late Roman Warlords, s. 41. 
Zachodniorzymskie ciągle potrzebowało wojska na ważniejszych frontach, należy przypuszczać, że motorem jego działania była raczej pozycja, jaką zajmował w dalmatyńskiej społeczności, niż sprawowana z nadania cesarskiego funkcja. Był zwolennikiem Aecjusza i zbuntował się przeciw Walentynianowi III po zamordowaniu wodza ${ }^{120}$. Zatem od 454 r. Dalmacja była rządzona przez osobę niezależną zarówno od Wschodu, jak i od Zachodu. Biorąc pod uwagę, że te wydarzenia miały miejsce bezpośrednio na granicy z Bizancjum, Marcjan musiał czujnie obserwować rozwój sytuacji. Nie mamy jednak żadnych informacji o jakichkolwiek działaniach podjętych przez którąkolwiek stronę. Być może cesarz akceptował przejęcie władzy przez Marcellina, jako fakt dokonany, lecz uważał go za kolejny przejaw fragmentacji władzy na Zachodzie. Możliwe, że utrzymywanie niezależności przez wodza utwierdzało Marcjana w przeświadczeniu, iż Rzym nie jest w stanie kontrolować wszystkich swych ziem, a zatem wspieranie go jest marnotrawstwem zasobów.

Marcjanowi w polityce zewnętrznej zależało przede wszystkim na stabilności. Nie interesowały go potencjalne zyski, zaś wyraźnie starał się unikać ryzyka i strat. Jego taktyka wobec zagrożenia ze strony Hunów skupiała się przede wszystkim na wzmocnieniu północnej granicy i powstrzymywaniu ich od agresji na ziemie Cesarstwa, jednocześnie nie tolerując żadnych ustępstw ${ }^{121}$. Choć był skłonny wesprzeć Aecjusza w 452 r., zrobił to tylko ze względu na korzyści, jakie wiązały się z takim postępowaniem: zarówno oferowane przez wodza koncesje polityczne, jak i możliwość relatywnie bezpiecznej neutralizacji zagrożenia ze strony Hunów. Aecjusz był dla Marcjana dobrym partnerem politycznym, lecz wraz z jego śmiercią Marcjan odciął się od wydarzeń dotyczących Zachodu. Z Walentynianem III nie mogło dojść do żadnych porozumień ze względu na skomplikowaną sytuację w sferze praw do tronu. Petroniusz Maksymus, Awitus, Majorian i Rycymer najpewniej nie uchodzili w oczach Marcjana za postaci godne zaufania. Ich pozycja była zbyt niepewna, a jako uwikłani w walki wewnętrzne mogli być postrzegani jako nieprzewidywalni. Polityka Marcjana wobec Wandalów kierowała się podobną ostrożnością, a władca wyraźnie nie miał ochoty angażować się w konflikt z królem Gejzerykiem. Ta zachowawcza polityka zewnętrzna była uzupełniana przez politykę wewnętrzną władcy. Marcjan dokonał reform w systemie podatkowym, ograniczył wydatki dworu i prowadził walkę z korupcją. O tym, że był sprawnym administratorem świadczy fakt, iż nakazał konsulom przeznaczyć pieniądze dotychczas rozrzucane wśród thumu

${ }^{120}$ Por. Procopius Caesariensis, De bellis III 6, 7, rec. Havry - Wirth, vol. 1, s. 336, 16-21, thum. Brodka, t. 1, s. 223.

${ }^{121}$ Nieustępliwość cesarza krytykuje Edward A. Thompson (Hunowie, s. 114), który zaznacza, że Marcjan zaprzepaścił w ten sposób osiagnięcia dyplomacji Teodozjusza. Jego zdaniem tylko fakt, że Attyla zawczasu postanowił wyprawić się na Zachód, uratował Cesarstwo Wschodnie przed katastrofą. Robert L. Hohlfelder (Marcian's Gamble, s. 62) twierdzi jednak, że traktat Anatoliusza i Nomusa nie był dla Attyli ostatecznym rozwiązaniem, zaś dążenie do konfrontacji było obarczone mniejszym ryzykiem niż kontynuacja linii politycznej Teodozjusza II. 
na utrzymanie miejskich akweduktów. Przedkładał zatem realne i trwałe korzyści dla miasta nad tanią popularność. Spokój w polityce zachodniej, który cesarz tak sobie cenił, pomagał w realizacji jego innych celów. Przeliczając dorobek jego niespełna siedmioletnich rządów na twardą walutę, Marcjan pozostawił skarb państwa ze 100000 funtów złota nadwyżki ${ }^{122}$.

Marcjan od początku swego panowania miał jasno określoną wizję polityki zachodniej. Nauczony doświadczeniem swego poprzednika, Teodozjusza II, nie zamierzał działać na wielu frontach jednocześnie, ale skoncentrował się na zagrożeniu ze strony Attyli. W latach 450-457 imperium Hunów praktycznie upadło, co w pewnej mierze było również zasługą cesarza. Panowanie Marcjana doprowadziło do wzmocnienia cesarstwa wschodniorzymskiego i zabezpieczenia jego północnej granicy. Z drugiej strony, jego polityka pośrednio przyczyniła się do rozkładu władzy cesarskiej na Zachodzie. Obojętność lub przesadna ostrożność cesarza wobec sytuacji kryzysowych, takich jak najazdy Wandalów oraz wewnętrzne walki o władzę, sprawiła, że niedający sobie z nimi rady Rzym popadł w anarchię. Mimo talentów politycznych i organizacyjnych Awitusa, Marcjan nie zrobił nic, by wspomóc jego kruche rządy i bezczynnie przyglądał się jego upadkowi. Trzeba jednak pamiętać, że dokonania Marcjana pośrednio umożliwiły jego następcy, Leonowi, prowadzenie aktywnej polityki zachodniej, nieskrępowanej, jak w przypadku Teodozjusza II, zagrożeniem ze strony Hunów.

THE WESTERN POLICY OF EMPEROR MARCIAN (450-457).

THE PROBLEM OF HUNS AND ITS INFLUENCE ON THE RELATIONSHIP BETWEEN THE EASTERN AND THE WESTERN ROMAN EMPIRE

\section{(Summary)}

The reign of Emperor Marcian came at the turning point in the history of the Late Roman Empire. The Empire struggled against the Hun and Vandal menace and an internal political crisis. The Western policy of Theodosius II, who attempted to keep a close relationship between both parts of the Empire, turned out to be a failure, and led to numerous defeats against barbarians. After his death, the military faction, opposed to his policies, chose its own candidate, Marcian, a former officer in service of a powerful general Aspar. The Emperor conceived a new line of Western policy, especially opposing the demands of Attila, the king of Huns. Marcian was reluctant to get involved in the matters of the Western Roman Empire, however, in 452 he sent an auxiliary force to Valentinian III, as a part of an agreement with Aetius, who convinced the Emperor to abandon his claim to the Eastern throne. Marcian also saw the opportunity to weaken Attila, and attacked

${ }^{122}$ Por. Twardowska, Rzymski Wschód, s. 101; Bury, History of the Later Roman Empire, s. $236-237$. 
the dwellings of his warriors beyond the Danube. After the death of Aetius, the Emperor did not support the Western Roman Empire, even when Rome was threatened and eventually sacked by Vandals. The cautious and pragmatic policy of Marcian helped the Byzantium to regain its power, and it led to neutralization of the Hun menace. The Emperor however did not make an attempt to save the Western Roman Empire from its internal political struggle and the Vandal attacks.

Key words: Late Antiquity, Emperor Marcian, Huns, the Western policy of Byzantium.

Słowa kluczowe: późny antyk, cesarz Marcjan, Hunowie, zachodnia polityka Bizancjum.

\section{BIBLIOGRAFIA}

\section{Źródła}

Acta synodorum habitarum Romae A. CCCCXCVIIII. DI. DII, ed. T. Mommsen, MGH Auctores Antiquissimi XII, Berolini 1894, 393-455.

Agathias Myrinaeus, Historiarum libri quinque, rec. R. Keydell, CFHB Series Berolinensis 2, Berolini 1967.

Candidus, Fragmenta, ed. R.C. Blockley, The Fragmentary Classicising Historians of the Later Roman Empire. Eunapius, Olympiodorus, Priscus and Malchus, vol. 2: Text, Translation and Historiographical Notes, Liverpool 1983, 464-471.

Chronicon Paschale, rec. L. Dindorf, Bonnae 1832.

Claudius Claudianus, De sexto consulatu Honorii Augustii, ed. with an English translation by M. Platnauer, w: Claudian, vol. 2, LCL 136, London 1922, 70-123.

Evagrius Scholasticus, Historia ecclesiastica, PG 86, 2416A - 2885A, thum. S. Kazikowski: Ewagriusz Scholastyk, Historia Kościoła, Warszawa 1990.

Hydatius, Chronica Subdita, ed. with an English translation by R.W. Burgess, w: The Chronicle of Hydatius and Consularia Constantinopolitana, two contemporary accounts of the final years of the Roman Empire, Oxford Classical Monographs, Oxford 1993, 70-123.

Ioannes Malalas, Chronographia, rec. J. Thurn, CFHB Series Berolinensis 35, Berolini et Novi Eboraci 2000.

Iordanes, Getica, ed. Th. Mommsen, MGH Auctores Antiquissimi V/1, Berolini 1882, 53138, thum. E. Zwolski: Kasjodor i Jordanes. Historia gocka czyli scytyjska Europa, Rozprawy Wydziału Historyczno-Filologicznego 49, Lublin 1984, 91-146.

Marcellinus Comes, Chronicon, ed. B. Croke, w: The Chronicle of Marcellinus, a translation and commentary (with a reproduction of Mommsen's edition of the text) Byzantina Australiensia 7, Sydney 1995, 1-52.

Olympiodorus, Fragmenta, ed. R.C. Blockley, w: The Fragmentary Classicising Historians of the Later Roman Empire. Eunapius, Olympiodorus, Priscus and Malchus, vol. 2: Text, Translation and Historiographical Notes, Liverpool 1983, 151-207.

Philostorgius, Historia ecclesiastica, von J. Bidez, bearb. F. Winkelmann: Philostorgius, Kirchengeschichte, mit dem Leben des Lucian von Antiochien und den Fragmenten eines arianischen Historiographen, GCS 21, Berlin 1972², 1-150.

Priscus, Fragmenta, ed. R.C. Blockley, w: The Fragmentary Classicising Historians of the Later Roman Empire. Eunapius, Olympiodorus, Priscus and Malchus, vol. 2: Text, Translation and Historiographical Notes, Liverpool 1983, 222-377. 
Procopius Caesariensis, De bellis libri, rec. J. Havry, addenda et corrigenda adiecit G. Wirth: Procopii Caesariensis Opera omnia, vol. 1: I-IV, vol. 2: V-VIII, Lipsiae 1962-1963, tłum. D. Brodka: Historia wojen, t. 1: Wojny z Persami i Wandalami, t. 2: Wojny z Gotami, Źródła Historyczne, Kraków 2013-2015.

Prosper Aquitanus, Epitoma Chronicon, ed. Th. Mommsen, MGH Auctores Antiquissimi

IX, Berolini 1892, 385-485.

Sidonius Apollinaris, Poems and Letters (Books I-II), ed. with an English translation by

W.B. Anderson, LCL 296, London 1956.

Theodorus LeCtor, Historia ecclesiastica, PG 86, 165A - 216B.

Theophanes, Chronographia, rec. C. de Boor, Lipsiae 1883.

Victor Vitensis, Historia persecutionis vandalicae, PL 58, 179D - 260A, thum. J. Czuj:

Wiktor z Wity, Dzieje prześladowania Kościoła w Afryce przez Wandalów, POK 14, Poznań 1930 [reprint: Poznań 2005].

\section{Opracowania}

Baldwin B., Priscus of Panium, „Byzantion” 50 (1980) 18-61.

Blockley R.C., The Fragmentary Classicising Historians of the Later Roman Empire. Eunapius, Olympiodorus, Priscus and Malchus, vol. 1, Liverpool 1981.

Bóna I., Das Hunnenreich, Stuttgart 1991.

Brodka D., Priskos von Panion und Kaiser Marcian. Eine Quellenuntersuchung zu Procop. 3,4,1-11, Evagr. HE 2,1, Theoph. AM 5943 und Nic. Kall. HE 15,1, ,Millenium" 9 (2012) 145-162.

Burgess R.W., A New Reading for Hydatius ,Chronicle” 177 and the Defeat of the Huns in Italy, „Phoenix” 42 (1988) 357-363.

Burgess R.W., The Accession of Marcian in the Light of Chalcedonian Apologetic and Monophysite Polemic, ByZ 86-87 (1993/1994) 27-68.

Bury J.B., History of the Later Roman Empire. From the Death of Theodosius I to the Death of Justinian, New York 1958.

Clover F.M., Gaiseric and Attila, „Historia” 22 (1973) 104-117.

Croke B., Dynasty and Ethnicity. Emperor Leo I and the Eclipse of Aspar, „Chiron” 35 (2005) 147-203.

Croke B., The Date and Circumstances of Marcian's Decease, A.D. 457, „Byzantion” 48 (1978) 5-9.

Gordon C.D., The Age of Attila. Fifth-Century Byzantium and the Barbarians, Ann Arbor Paperback 111, Ann Arbor 1961.

Gračanin H. - ŠKrgulja J., The Ostrogoths in the Late Antique South Pannonia, „Acta Archeologica Carpathica" 49 (2014) 165-205.

Gračanin H., The Huns and South Pannonia, „Byzantinoslavica” 64 (2006) 29-76.

GraČAnIN H., The Western Roman Embassy to the Court of Attila in A.D. 449, „Byzantinoslavica" 61 (2003) 53-74.

Heather P., Goths and Romans 332-489, Oxford 1991.

Heather P., Imperia i barbarzyńcy, tłum. J. Szczepański, Historia - Rebis, Poznań 2010.

HeAther P., The Huns and the End of the Roman Empire in Western Europe, „English Historical Review" 110 (1995) 4-41.

Heather P., Upadek Cesarstwa Rzymskiego, tłum. J. Szczepański, Poznań 2006.

Hohlfelder R.L., Marcian's Gamble. A Reassessment of Eastern Imperial Policy toward Attila AD 450-453, „Americal Journal of Ancient History” 9 (1984) 54-69.

Holum K.G., Theodosian Empresses: Women and Imperial Dominion in Late Antiquity, The Transformation of the Classical Heritage 3, Berkeley 1982. 
JuRewicz O., Historia literatury bizantyńskiej, Wrocław 1984.

KAEGI W.E., Byzantium and the Decline of Rome, Princeton 1968.

KuRANC J., Wyprawa poselstwa wschodnio-rzymskiego na dwór króla Attyli, „Meander” 12 (1956) 20-36.

LeszKa M.B. - LeszKa M.J., Zarys dziejów Konstantynopola w latach 337-602, w: Konstantynopol - Nowy Rzym. Miasto i ludzie w okresie wczesnobizantyńskim, red. T. Wolińska - M.J. Leszka, Warszawa 2011, 42-101.

LeszKa M.J., Uzurpacje w Cesarstwie Bizantyńskim w okresie od IV do połowy IX wieku, Byzantina Lodziensia 4, Łódź 1999.

MacGeorge P., Late Roman Warlords, Oxford Classical Monographs, Oxford - New York 2002.

MąCZYŃSKA M., Światło z popiołu. Wędrówki ludów w Europie w IV i V wieku, Warszawa 2013.

Maenchen-Helfen O., The World of Huns. Studies in Their History and Culture, Berkeley 1973.

Mathisen R.W., Avitus, Italy and the East in A.D. 455-456, „Byzantion” 51 (1981) 232-247.

Millar F., A Greek Roman Empire. Power and Belief under Theodosius II 408-450, Sather Classical Lectures 64, Berkeley 2007.

Oost S., Aetius and Majorian, CPh 59 (1964) 23-29.

Pawlak M., Aecjusz i barbarzyńcy, Mediterraneum 5, Kraków 2007.

PaWlak M., Walka o władzę w Rzymie w latach 425-435, Toruń 2004.

Rohrbacher D., Historians of Late Antiquity, London 2002.

Rouche M., Attyla i Hunowie. Ekspansja barbarzyńskich nomadów IV-V wiek, thum. J. Jedliński, Warszawa 2011.

Stein E., Histoire du Bas-Empire, t. 1, éd. française par J.R. Palanque, Paris 1959.

STRZELCZyк J., Wandalowie i ich afrykańskie państwo, Warszawa 1992.

Świat rzymski w V wieku, red. R. Kosiński - K. Twardowska, Kraków 2010.

The Prosopography of the Later Roman Empire, vol. 2: A.D. 395-527, ed. H.J.M. Jones - J.R. Martindale - J. Morris, Cambridge 1980.

Thompson E.A., Hunowie, oprac. P. Heather, thum. B. Malarecka, Warszawa 2015.

Thompson E.A., The Foreign Policies of Theodosius II and Marcian, „Hermathena” 76 (1950) 58-75.

TyszKIEwicz L.A., Hunowie w Europie. Ich wptyw na Cesarstwo Wschodnie i Zachodnie oraz na ludy barbarzyńskie, Acta Universitatis Vratislaviensis 2695, Wrocław 2004.

URBANIEC A., Wptyw patrycjusza Aspara na cesarskq elekcję Leona, „U Schyłku Starożytności. Studia Źródłoznawcze" 11 (2011) 173-201.

Vademecum historyka starożytnej Grecji i Rzymu, t. 3: Źródłoznawstwo czasów późnego antyku, red. E. Wipszycka, Warszawa 1999.

VernADSKy G., Flavius Ardabur Aspar, „Südost-Forschungen” 6 (1941) 38-73.

WILCZYŃSKI M., Zagraniczna $i$ wewnętrzna polityka afrykańskiego państwa Wandalów, Prace Monograficzne Wyższej Szkoły Pedagogicznej w Krakowie 176, Kraków 1994.

Wolfram H., Historia Gotów, thum. A. Darda-Staab i inni, Warszawa - Gdańsk 2003.

ZоŁoтEŃKi D., Galia u schyłku panowania rzymskiego: administracja cywilna $i$ wojskowa w latach 455-486, Notos. Scripta Antiqua et Byzantina 6, Kraków 2011. 
